\title{
Comprehensive Assessment from Optimum Biodiesel Yield to Combustion Characteristics of Light Duty Diesel Engine Fueled with Palm Kernel Oil Biodiesel and Fuel Additives
}

\author{
Senthur Prabu Sabapathy ${ }^{1}$, Asokan Morappur Ammasi ${ }^{1, *}$, Esmail Khalife ${ }^{2,3}$, Mohammad Kaveh ${ }^{4}$, \\ Mariusz Szymanek ${ }^{5, * \mathbb{D}}$, Gokul Kuruvakkattu Reghu ${ }^{1}$ and Prathiba Sabapathy ${ }^{6}$
}

Citation: Sabapathy, S.P.; Ammasi, A.M.; Khalife, E.; Kaveh, M.;

Szymanek, M.; Kuruvakkattu Reghu, G.; Sabapathy, P. Comprehensive Assessment from Optimum Biodiesel Yield to Combustion Characteristics of Light Duty Diesel Engine Fueled with Palm Kernel Oil Biodiesel and Fuel Additives. Materials 2021, 14, 4274. https://doi.org/10.3390/ ma14154274

Academic Editor: Eulogio Castro

Received: 26 June 2021

Accepted: 26 July 2021

Published: 30 July 2021

Publisher's Note: MDPI stays neutral with regard to jurisdictional claims in published maps and institutional affiliations.

Copyright: (c) 2021 by the authors. Licensee MDPI, Basel, Switzerland. This article is an open access article distributed under the terms and conditions of the Creative Commons Attribution (CC BY) license (https:/ / creativecommons.org/licenses/by/ $4.0 /)$.
1 School of Mechanical Engineering, Vellore Institute of Technology (VIT), Vellore 632014, India; senthurprabu.s@vit.ac.in (S.P.S.); gokul20000@gmail.com (G.K.R.)

2 Department of Civil Engineering, Cihan University-Erbil, Kurdistan Region, Iraq; esmail.khalife@su.edu.krd

3 Biofuel Research Team (BRTeam), Terengganu, Malaysia

4 Department of Biosystem Engineering, Faculty of Agriculture and Natural Resources,

University of Mohaghegh Ardabili, Ardabil 56199-11367, Iran; sirwankaweh@gmail.com

5 Department of Agricultural, Forest and Transport Machinery, University of Life Sciences in Lublin, Głęboka 28, 20-612 Lublin, Poland

6 Department of Chemical Engineering, SSN College of Engineering, Chennai 603110, India; prathibabiochm@gmail.com

* Correspondence: asokan.ma@vit.ac.in (A.M.A.); mariusz.szymanek@up.lublin.pl (M.S.)

\begin{abstract}
Biodiesel is considered as a key prospective renewable energy source in India. Hence, a study was carried out for the improvement of palm kernel oil biodiesel production using a transesterification process at different molar ratios. This study comprehensively examined all aspects of biodiesel from optimum production to the effect of additives on its combustion behavior. The optimum yield condition was validated with the MINITAB-17 software and analyzed using the Taguchi method. Two different additives, $5 \%$ diethyl ether (DEE) and $2000 \mathrm{ppm}$ Butylated hydroxyltoluene (BHT), were also experimented. Engine experiments were conducted at constant speed (1500 rpm) and five different engine loads $(0,25,50,75$ and 100\%) on a single-cylinder direct injection diesel engine. Heat release rate, brake specific fuel consumption, brake thermal efficiency, engine emissions, such as $\mathrm{CO}, \mathrm{HC}$, NOx, and smoke opacity were analyzed. The maximum palm kernel oil (PKO) biodiesel yields, obtained at $55^{\circ} \mathrm{C}$, for the $\mathrm{KOH}$ and $\mathrm{NaOH}$ catalysts were $86.69 \%$ and $75.21 \%$ at the molar ratio of 6:1. B20BHT combustion showed 4.6\% higher brake thermal efficiency (BTE). NOx emission was reduced by $19.4 \%$, compared to the diesel fuel values. DEE resulted in higher CO and $\mathrm{HC}$ emissions compared to diesel fuel values by $39.2 \%$ and $7.6 \%$, respectively, whereas smoke emission was improved by $11.5 \%$.
\end{abstract}

Keywords: biodiesel; diesel engine; combustion; transesterification; BHT; DEE

\section{Introduction}

In the current scenario, the world energy resources are quickly depleting every year due to the rising trend of industrialization, as well as modernization. Crude oil is the main source to fulfill the demand of energy, but it leads to environmental degradation. Moreover, the products of combustion, such as $\mathrm{NOx}, \mathrm{SO}_{2}$ and $\mathrm{CO}_{2}$, result in global warming. The atmosphere problems caused by the consumption of fossil fuels alongside petroleum scarcity have led researchers to explore renewable energy resources, i.e., derivatives of animal fats, vegetable oils and waste oils. Since the previous century, the thought of vegetableoil-based fuel (biodiesel) to operate diesel engines has been on the world stage. Biodiesel as a substitute fuel has been getting great attention among the world policy makers due to its positive properties like low exhaust gases emissions, non-toxic characteristics and biodegradability, as well as renewability $[1,2]$. This fuel is used in compression ignition 
(CI) engines with no or slight modification. However, due to the greater viscosity, flash point, pour point, etc., vegetable oils must be transesterified [3], that is, the triglyceride molecules are cracked into methyl ester (biodiesel). Lipids react with alcohol to form esters and a by-product, glycerol. For this aim, methanol and ethanol are widely used alcohols. Biodiesel blended with diesel has become very popular, nowadays, because of its increased lubricity, which reduces wear and tear of engine components and increases safety. while storing and transporting of biodiesel are effortless due to its high flash point and its compatibility in blending with diesel fuel. However, biodiesel has some limitations, such as clogging, due to its greater viscosity, high flash point and higher NOx emissions, compared to diesel fuel [4-6]. Therefore, it is essential to refine biodiesel to obtain better quality and ensuring about its performance and emissions. Low acid value, higher cetane number, low viscosity, low specific gravity and high flash point are some of the major factors for the quality of biodiesel $[7,8]$. Among all biodiesel resources, non-edible oils are more interesting than edible oils because of competition between food and energy. In that aspect, palm kernel oil (PKO), as non-edible oil, can be conceived as potential inexpensive biodiesel feedstock and as an alternative compared with the new non-edible/edible oils. The main advantage of PKO is its ready availability in India and it is being reused for the production of biodiesel $[9,10]$. There are several papers on converting PKO into biodiesel. For example, Alamu et al. [11] investigated biodiesel production through transesterification of $\mathrm{PKO}$ with ethanol and in the presence of $\mathrm{NaOH}$ as catalyst and glycerol as a byproduct. They reported a high yield biodiesel production of up to $96 \%$. Beside the method of biodiesel production, there are several parameters which impact biodiesel production yield. For instance, Aboelazayem et al. [12] studied very important variables which influence biodiesel yield, such as molar ratio, catalyst concentration, temperature, stirring rate and time, to maximize biodiesel production from castor oil. They found that molar ratio has a directly proportional relationship with biodiesel yield in a range of 3:1-7:1. However, further increasing molar ratio has no valuable effect on biodiesel yield. A similar observation was reported by Silitonga et al. [13] in their study, where they concluded that the effect of molar ratio has a highly statistical significant effect on biodiesel yield in a molar ratio range of 3:1-6:1. They reported that, at an M:O molar ratio higher than 9:1, the increase of M:O molar ratio has a negative effect on biodiesel yield, resulting in decreasing it. PKO biodiesel combustion was investigated from many aspects. Ayetor et al. [14] studied the performance and emission characteristics of PKO biodiesel-diesel blends in a direct injection (DI) diesel engine and reported that the emission characteristics of $\mathrm{HC}$ and CO of B100 were reduced by $55 \%$ and $41 \%$, whereas NOx increased by $10 \%$, in comparison with diesel fuel values. They also reported $6 \%$ increase for BSFC. Nwakaire et al. [15] studied engine performance with different ratios of biodiesel blended in diesel fuel and claimed an improvement, compared to diesel fuel, of up to $26 \%$; in addition, they reported low BSFC for biodiesel combustion. However, one of the major problems with biodiesel application as fuel is its oxidation stability. For this aim, many studies have focused on the effect of antioxidants on biodiesel properties and combustion. For instance, Prabu et al. [16] studied the effect of Butylated hydroxyltoluene (BHT) and n-butanol on diesel engine emission parameters fueled with diesel-waste cooking oil (WCO) biodiesel blends. They investigated that the inclusion of BHT into B30 resulted in higher brake specific fuel consumption (BSFC), by 7.3\%, and lower BTE, by $4.6 \%$, compared with diesel, whereas the heat release rate (HRR) was almost comparable to diesel fuel. In addition, the oxygenated content of n-butanol added to the $\mathrm{B} 30$ blend showed a $\mathrm{CO}$ emission reduction of $37.5 \%$ and a NOx emission increment of $9 \%$, compared to diesel. In an interesting investigation, Ryu [17] considered the effect of different antioxidants on biodiesel oxidation stability, as well as diesel engine combustion parameters, and reported that the antioxidants efficiency is in the order of $\alpha$-tocopherol $<\mathrm{BHT}<\mathrm{BHA}<\operatorname{PrG}<\mathrm{TBHQ}$. They pointed out that all of the antioxidants had lower BSFC than neat biodiesel fuel. Ndayishimiye and Tazerout [18] carried out a diesel engine test using palm oil (PO) biodiesel blended with diesel fuel to evaluate exhaust gas emission and engine performance characteristics. They reported high 
BSFC, increasing (2-25\%) for different preheated biodiesel ratios, while BTE showed a similar trend as diesel combustion. HC emission was drastically reduced by $30-65 \%$ with preheated oil and WCO + PO biodiesel, compared to diesel. They found NOx emission was reduced with PO biodiesel, compared to diesel fuel.

To improve some biodiesel drawbacks, such as viscosity, researchers include additives, such as diethyl ether (DEE), alcohol, etc. For example, Imdadul et al. [19] investigated the combustion of Calophyllum inophyllum biodiesel containing pentanol in a DI diesel engine and stated that the added alcohol improved the burning premixed and diffusion stages of combustion. In another study, Qi et al. [20] investigated the effect of a biodieseldiesel (B30) blend containing ethanol (5\%) and DEE (5\%) on diesel engine combustion and observed that the addition of DEE led to a reduction in BSFC. They reported that the combustion of DEE additive led to higher HRR and peak pressure of the cylinder at higher engine loads. In another study, Imtenan et al. [21] tried to find the effect of n-butanol and diethyl included in diesel-jatropha biodiesel blends and stated that DEE showed lower BSFC than neat diesel at low engine speeds, which actually points out better combustion quality due to their high oxygen content and low viscosity, compared to n-butanol. Apart from viscosity, biodiesel degradation is also another important problem which influences its combustion quality. The addition of antioxidant additives into the biodiesel fuel can properly prevent from its oxidation to a reasonable level. The examination of various studies showed that almost studies have just focused on the effect of the molar ratio of the biodiesel production or have considered the biodiesel combustion behavior. To the best of the authors' knowledge, there is no research which has targeted all aspects of biodiesel fuel from production condition to combustion, as well as the effect of additives. Therefore, the purpose of the present study was to comprehensively scrutinize the PKO biodiesel optimum production and make a comparison on combustion characteristics and exhaust gases of DEE (10 vol\%) and BHT (2000 ppm) additives. Seven different biodiesel-diesel blends (pure diesel, B20, B30, B40, B100, B20DEE and B20BHT) were examined under five engine loads (no load, 20, 40, 60, 80 and 100\%) and constant speed (1500 rpm) of a 4-stroke, water cooled, one cylinder DI diesel engine.

\section{Materials and Methods}

PKO is an available, abundant and low cost source for biodiesel production. The schematic steps of the procedure adopted for biodiesel production from PKO is illustrated in Figure 1.

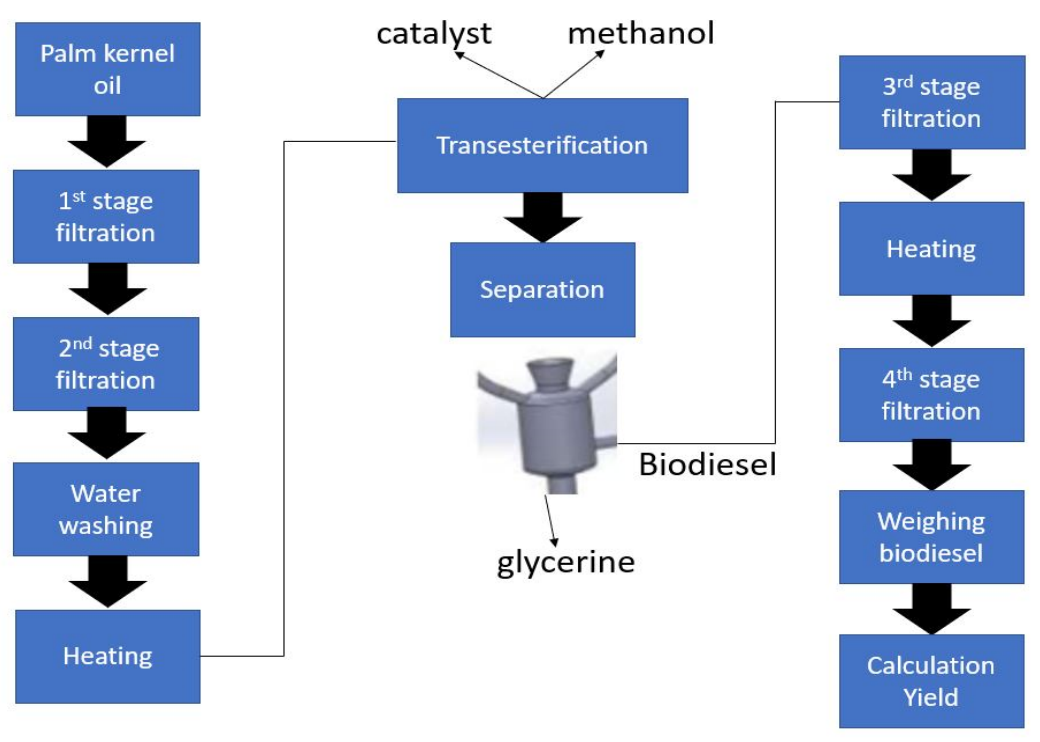

Figure 1. Flow chart of the transesterification process. 


\subsection{Transesterification Process}

The transesterification process is affected by the type and quantity of alcohol, time and temperature of the reaction, type and quantity of the catalyst and amount of free fatty acid (FFA). As above mentioned, ethanol and methanol are commonly and widely used alcohols. However, due to the low cost and reactivity, methanol was used for biodiesel production in the present work. The transesterification reaction was performed in two steps. First, an acid catalyzed reaction was performed using $\mathrm{H}_{2} \mathrm{SO}_{4}$ (sulphuric acid) in the presence of methanol; the second step was carried out using a base catalyzed reaction with potassium hydroxide $(\mathrm{KOH})$ and sodium hydroxide $(\mathrm{NaOH})$, separately. In the acid catalyzed reaction, triglycerides were converted into diglycerides; then, during the base catalyzed reaction, diglycerides were converted into mono glycerides and, at the end, monoglycerides into glycerol.

The production of PKO biodiesel samples was performed through methanol at 3 different ratios, 3:1, 6:1 and 9:1 (i.e., methanol to oil ratio or molar ratio), 3 different reaction temperatures $\left(50,55\right.$ and $60{ }^{\circ} \mathrm{C}$ ) and a reaction time of $45 \mathrm{~min}$, with the $\mathrm{H}_{2} \mathrm{SO}_{4}$ acid catalyst in the 1st step and $\mathrm{KOH}$ and $\mathrm{NaOH}$ as base catalysts in the 2nd step.

The PKO was filtered through a strainer, initially, to remove the large, suspended particles; $3 \%$ of orthophosphoric acid was added to the oil and left for $3 \mathrm{~h}$, for settling heavy particles; then, the oil was separated using a filter paper (Watman 6: $25 \mu \mathrm{m}$ ); further, the oil was washed with distilled water. Water was then removed automatically from the bottom of the flask, because of the density difference between water and oil; however, the remaining water was removed by heating the oil to $100{ }^{\circ} \mathrm{C}$ and maintaining it for $3-4 \mathrm{~h}$, otherwise, the moisture in the oil would have caused negative effects on the biodiesel yield. Thereafter, the FFA value of PKO was found using the titration method, in which the solution of oil $(1 \mathrm{ml})$, isopropyl alcohol $(10 \mathrm{~mL})$ and $2-3$ drops of phenolphthalein was titrated against a $\mathrm{KOH}$ solution ( $1 \mathrm{~kg}$ of $\mathrm{KOH}+1 \mathrm{~L}$ of water); the color change to pink was considered as the titration values. The acidic value was estimated using Equation (1) [22]:

$$
\text { Acidic value }(A V)=\left(v_{e q}-b_{e q}\right) N \frac{56.1 \mathrm{gmol}^{-1}}{W_{\text {oil }}}
$$

where, $v_{e q}$ is the final reading $(\mathrm{mL}), b_{e q}$ the initial reading $(\mathrm{mL}), N$ the normality of $\mathrm{KOH}$ and $W_{\text {oil }}$ the oil weight $(\mathrm{g})$.

$$
\text { FFA Value }=\mathrm{AV} \times 0.52
$$

The FFA value was calculated from Equation (2). Accordingly, the amount of catalyst required for transesterification reaction was obtained through the calculating FFA value in volume basis $(v / v)$, i.e., 1.067, 1.152 and $1.408 \mathrm{~g}$ for the molar ratios of 3:1, 6:1 and 9:1, for the $\mathrm{KOH}$ catalyst, whereas, for the $\mathrm{NaOH}$ catalyst, 1.152, 1.195 and $1.707 \mathrm{~g}$ for the molar ratios of 3:1, 6:1 and 9:1.

A volume of $100 \mathrm{~mL}$ of $\mathrm{PKO}$ was taken in a beaker and then added into the $\mathrm{KOH}+$ methanol solution, which was prepared separately. Thereafter, the solution with the reaction time of $45 \mathrm{~min}$ was stirred using the orbital shaker at a speed of $200 \mathrm{rpm}$. Afterward, the mixture was kept for $12 \mathrm{~h}$ to let the glycerine settle down at the bottom of the beaker. After that, the biodiesel was washed and heated to $65^{\circ} \mathrm{C}$, to remove the traces of $\mathrm{KOH}$ or methanol. Finally, the biodiesel collected was filtered and weighed to find the yield, which was calculated using Equation (3) [23]:

$$
\text { Yeild } \%=\frac{\text { Weight of biodiesel }}{\text { weight of oil }}
$$

The same process was repeated for each sample $(100 \mathrm{~mL})$ of $\mathrm{PKO}$ with various different alcohol ratios $(3: 1,6: 1,9: 1)$ and three different temperatures $\left(50,55\right.$ and $\left.60^{\circ} \mathrm{C}\right)$ for a reaction time of $45 \mathrm{~min}$, employing $\mathrm{KOH}$ and $\mathrm{NaOH}$, separately, as catalysts. The range and levels for different parameters are given in Table 1. 
Table 1. Range and levels of parameters.

\begin{tabular}{ccccc}
\hline \multirow{2}{*}{ Variables } & Symbol & \multicolumn{3}{c}{ Range and Levels } \\
\cline { 3 - 5 } & & $\mathbf{- 1}$ & $\mathbf{0}$ & $\mathbf{1}$ \\
\hline Temperature $\left({ }^{\circ} \mathrm{C}\right)$ & $\mathrm{T}$ & 50 & 55 & 60 \\
Alcohol to molar ratio & $\mathrm{MR}$ & $3: 1$ & $6: 1$ & $9: 1$ \\
Catalyst & $\mathrm{C}$ & & $\mathrm{KOH}$ & $\mathrm{NaOH}$ \\
\hline
\end{tabular}

\subsection{Biodiesel Production Model}

The MINITAB-17 software was used for the statistical analysis of the experimental data and the correlation of the parameters to the biodiesel yield (\%) was given by a fully quadratic model in Equation (4):

$$
\text { Yield }(\%)=a_{0}+\sum_{n=1}^{4} a_{n} x_{n}+\sum_{n=1}^{4} a_{n n} x_{n}{ }^{2}+\sum_{n=1}^{4} \sum_{m=n+1}^{4} a_{n m} x_{n m}
$$

where, $x_{n}, x_{n m}$ are uncoded independent variables, $a_{0}$ is a constant and $a_{n}, a_{n n}, a_{n m}$ are the regression coefficients.

\subsection{Properties of $P K O$}

\subsubsection{Flash Point and Fire Point}

The flash point and fire point are important thermal properties of a fuel which give an idea of the lowest temperature where the vapors of the fuel start to ignite in the presence of a source of ignition. With the help of an apparatus called Pensky-Martens (Aimil Ltd., New Delhi, India), the flash and fire points were measured for the PKO biodiesel-diesel blends, as per the ASTM D93 standard. As can be observed from Table 2, the flash point of PKO biodiesel was higher than that of diesel fuel. As from a safety point of view, pure $\mathrm{PKO}$ biodiesel is a better option, compared to diesel.

Table 2. Properties diesel-PKO biodiesel blends and neat diesel fuel.

\begin{tabular}{cccccccc}
\hline Properties & Standard Values & B100 & B20 & B30 & B40 & DIESEL & Testing Procedure \\
\hline Density, $20{ }^{\circ} \mathrm{C}\left(\mathrm{kg} / \mathrm{m}^{3}\right)$ & $680-970$ & 844 & 832 & 834 & 836 & 830 & ASTM D1298 \\
Kinematic viscosity, $40{ }^{\circ} \mathrm{C}\left(\mathrm{mm}^{2} / \mathrm{s}\right)$ & $1.9-6$ & 4.2 & 3.12 & 3.28 & 3.39 & 2.75 & ASTM D445 \\
Flash point $\left({ }^{\circ} \mathrm{C}\right)$ & $60-190{ }^{\circ} \mathrm{C}$ & 170 & 84 & 95 & 105 & 62 & ASTM D93 \\
Fire point $\left({ }^{\circ} \mathrm{C}\right)$ & - & 172 & 92 & 101 & 112 & 70 & ASTM D93 \\
Calorific value $(\mathrm{MJ} / \mathrm{kg})$ & - & 38.2 & 42.68 & 42.12 & 41.56 & 43.8 & ASTM D240 \\
Cetane number $(\mathrm{CN})$ & $>40$ & 52 & - & - & - & 53 & ASTM D613 \\
\hline
\end{tabular}

\subsubsection{Kinematic Viscosity and Density}

Kinematic viscosity is a key physical property of a fuel, which influences combustion. By using the Redwood viscometer (Aimil Ltd., New Delhi, India), the kinematic viscosity was found for the diesel-PKO biodiesel blends, as per the ASTM D 445 standard, and tabulated in Table 2. The kinematic viscosity of the diesel-PKO biodiesel blends was measured at $40{ }^{\circ} \mathrm{C}$ and it was observed that the viscosity of B100 $\left(4.2 \mathrm{~mm}^{2} / \mathrm{s}\right)$ was higher than that of diesel fuel $\left(2.75 \mathrm{~mm}^{2} / \mathrm{s}\right)$. However, the measured values of kinematic viscosities were inside the range of biodiesel. Further, the average density of the diesel-PKO biodiesel blends was measured at $20^{\circ} \mathrm{C}$, as per the ASTM 1298 standard, and the value of PKO was $844 \mathrm{~kg} / \mathrm{m}^{3}$, whereas, for diesel, it was $830 \mathrm{~kg} / \mathrm{m}^{3}$. The density of PKO biodiesel was greater, by $1.6 \%$, than the diesel fuel one. The density of the PKO biodiesel produced was somewhat higher than that of diesel fuel; however, it was inside the range of ASTM standards. 


\subsubsection{Calorific Value (CV)}

The CV is an important thermal property of fuels which shows the amount of heat energy produced during the complete burning per unit quantity of fuel burnt. A bomb calorimeter (EIE Instruments Private Ltd., Ahmedabad, India) was used to determine the CV of diesel-biodiesel blends (ASTM D 240 standard); the results are presented in Table 2. The calculated CV of PKO was $38.2 \mathrm{MJ} / \mathrm{kg}$, whereas, for diesel fuel, it was $43.8 \mathrm{MJ} / \mathrm{kg}$. The CV of PKO biodiesel was approximately $12.78 \%$ lower than the diesel fuel one, which entails that the amount of biodiesel injected needs to be more to attain the same power as diesel fuel.

\subsubsection{Cetane Number $(\mathrm{CN})$}

The cetane number $(\mathrm{CN})$ is a parameter which determines the ignition delay period (the period between fuel injection and SOC). As per the ASTM D613 standard, the CN of PKO biodiesel was acquired from Bello et al. [9]; the obtained results are tabulated in Table 2. In this study, the CN of PKO biodiesel was 52, which is lower than the diesel fuel one, 53 , which might slightly increase the time of ignition delay.

\subsection{Preparing Samples}

To prepare biodiesel-diesel blend, the obtained PKO biodiesel was blended with diesel by volume, i.e., B20 (20\% PKO biodiesel $+80 \%$ diesel), B30 (30\% PKO biodiesel $+70 \%$ diesel), B40 (40\% PKO biodiesel $+60 \%$ diesel) and B100 (100\% palm kernel oil biodiesel), as shown in Figure 2. Here, pure diesel was employed as control sample.

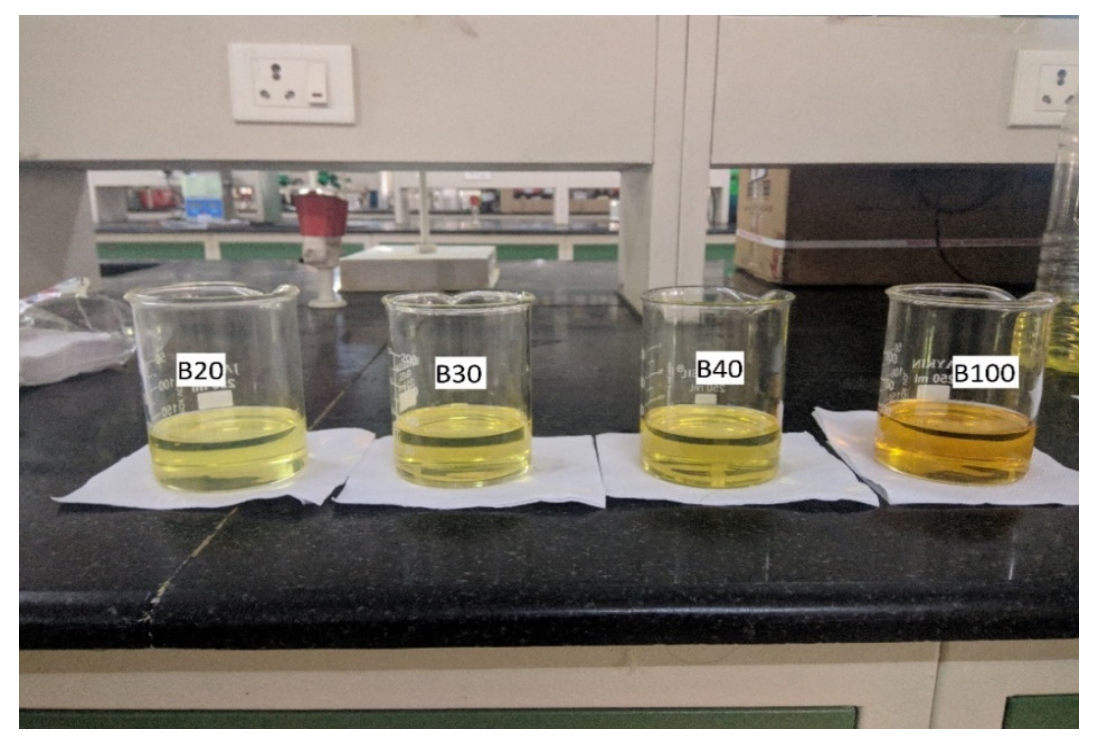

Figure 2. Photographical view of PKO blends.

For preparing other blends, DEE and BHT additives were included separately with B20. DEE additive was added into B20 to prepare a B20 + DEE fuel blend by blending $100 \mathrm{~mL}$ of DEE in $900 \mathrm{~mL}$ of B20 blend. For the next samples, BHT was added into B20 to obtain a B20 + BHT fuel blend by adding 2000 ppm BHT in $1000 \mathrm{~mL}$ of B20.

The effects of catalyst, temperature and methanol ratio for different trials on the biodiesel yield (\%) of the results obtained from the experiment and predicted by model proposed are tabulated in Table 3.

From Table 3, the maximum biodiesel yield $(86.69 \%)$ using the catalyst $\mathrm{KOH}$ was obtained from the molar ratio of $6: 1$ at a reaction temperature of $55{ }^{\circ} \mathrm{C}$, whereas the maximum yield was $88.01 \%$, according to the proposed model. The maximum yield using the $\mathrm{NaOH}$ catalyst $(75.21 \%)$ was obtained from the molar ratio of $6: 1$ at a temperature of $55^{\circ} \mathrm{C}$ and, for the model generated by the software, it was $73.37 \%$. PKO biodiesel was 
produced with the help of the highest yield parameters obtained (Table 3), i.e., catalyst, reaction temperature and molar ratio. The thermophysical properties of diesel-PKO biodiesel blends were obtained using ASTM D6751 standard and are represented in Table 2. The table clearly shows that the PKO biodiesel produced by transesterification process was within the range of ASTM standards.

Table 3. Yield (\%) of PKO biodiesel.

\begin{tabular}{|c|c|c|c|c|}
\hline Catalyst & Temperature $\left({ }^{\circ} \mathrm{C}\right)$ & Methanol Ratio & Yield (Experimental) (\%) & Yield (Model) (\%) \\
\hline \multirow{9}{*}{$\mathrm{KOH}$} & \multirow{3}{*}{50} & $3: 1$ & 82.3215 & 79.6506 \\
\hline & & $6: 1$ & 85.6495 & 86.3099 \\
\hline & & $9: 1$ & 84.4795 & 86.0788 \\
\hline & \multirow{3}{*}{55} & $3: 1$ & 83.4956 & 81.3492 \\
\hline & & $6: 1$ & 86.6935 & 88.0085 \\
\hline & & $9: 1$ & 85.7155 & 87.7774 \\
\hline & \multirow{3}{*}{60} & $3: 1$ & 82.6175 & 80.0396 \\
\hline & & $6: 1$ & 86.0165 & 86.6989 \\
\hline & & $9: 1$ & 85.3915 & 86.4678 \\
\hline \multirow{9}{*}{$\mathrm{NaOH}$} & \multirow{3}{*}{50} & $3: 1$ & 62.3735 & 65.0131 \\
\hline & & $6: 1$ & 72.6465 & 71.6724 \\
\hline & & $9: 1$ & 72.6955 & 71.4413 \\
\hline & \multirow{3}{*}{55} & $3: 1$ & 64.4395 & 66.7116 \\
\hline & & $6: 1$ & 75.2135 & 73.3710 \\
\hline & & $9: 1$ & 74.9999 & 73.1399 \\
\hline & \multirow{3}{*}{60} & $3: 1$ & 62.9185 & 65.4021 \\
\hline & & $6: 1$ & 72.1025 & 72.0614 \\
\hline & & $9: 1$ & 73.4535 & 71.8303 \\
\hline
\end{tabular}

\subsection{Engine Combustion Setup}

Performance and emission characteristics of all prepared samples were carried out using a single-cylinder, 4-stroke DI diesel engine (Kirloskar, Pune, India), which was operated at a constant engine rotation of $1500 \mathrm{rpm}$. The diesel engine was paired with an eddy current dynamometer for varying loads, from 0 to $100 \%$, in steps of $25 \%$. A schematic of engine test setup is shown in Figure 3. In addition, the specifications of the engine are tabulated in Table 4.

An AVL gas analyzer (DIGAS $444 \mathrm{~N}$ model)(Indiaprivate Ltd., Hyderabad, India) was employed to measure the NOx, $\mathrm{CO}$ and unburned hydrocarbon (UHC) emissions of the engine. In addition, the smoke intensity was measured by an AVL $437 \mathrm{C}$ smoke opacimeter. A thermocouple (K-type) was provided to evaluate the inlet air and exhaust gas temperature, cooling water and lubricating oil temperature. HRR were measured by employing an AVL 617 Indimeter V2.0 (AVL India private Ltd., Hyderabad, India). The data (position of crank angle during the start of combustion (SOC), HRR and peak pressure) were recorded and a file was generated during the test by the Indimeter software V2.0. A miniature pressure sensor AVL GH12D was employed for measuring the variation of pressure in-cylinder vs. crank angle. The encoder was used to obtain the position of the crank angle. Additionally, a piezoelectric amplifier (AVL 3066A02) was employed to intensify the output signal from the miniature sensor. 


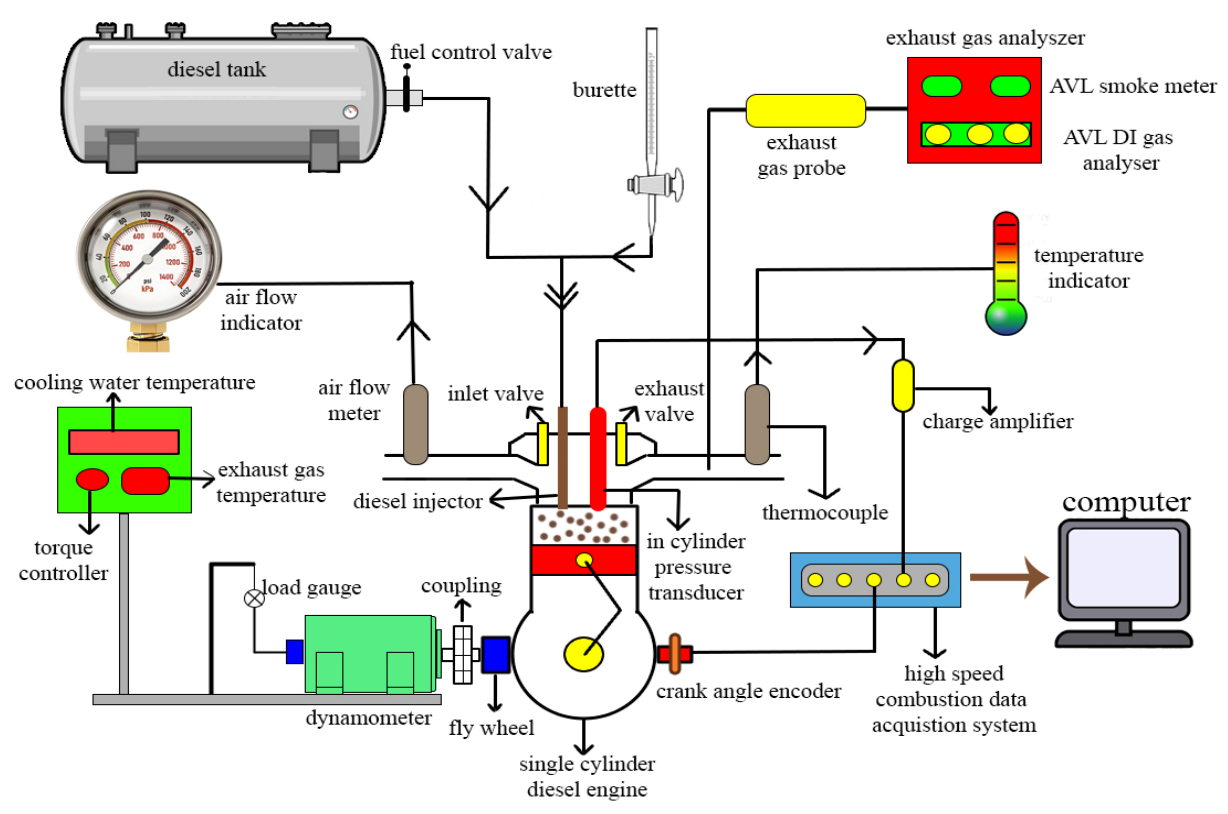

Figure 3. Schematic diagram of experimental engine setup.

Table 4. Engine specifications.

\begin{tabular}{cc}
\hline Make & Kirloskar (Direct Injection, Water Cooled, 1500 rpm) \\
\hline Model & TAF 1 $(5.2 \mathrm{~kW}$ power $)$ \\
Ratio of compression & $17.5: 1$ \\
Bore $\times$ stroke $(\mathrm{mm})$ & $87.5 \times 110 \mathrm{~mm}$ \\
Swept volume & $661 \mathrm{~cm}^{3}$ \\
Start of injection and pressure & $24^{\circ}$ BTDC and $21 \mathrm{MPa}$ \\
Connecting rod length & $234 \mathrm{~mm}$ \\
\hline
\end{tabular}

\subsubsection{Testing Conditions}

During the initial starting of the diesel engine, the neat diesel fuel was used to operate in full throttle opening condition at a constant speed of $1500 \mathrm{rpm}$ to run at least $30 \mathrm{~min}$ to reach a steady state condition. The lubricating oil temperature was ensured to be within the range $85-90{ }^{\circ} \mathrm{C}$, whereas the temperature of cooling water was maintained at $60{ }^{\circ} \mathrm{C}$.

Before starting the engine tests of diesel-PKO biodiesel blends, the neat diesel fuel was first tested by changing loads from 0 to $100 \%$, in steps of $25 \%$, after it was ensured that the diesel engine reached a steady state condition. For each load, the engine was set to run at $1500 \mathrm{rpm}$. A time interval for $10 \mathrm{cc}$ consumption of fuel was entered with the help of a stopwatch. The data, such as power output, in-cylinder pressure, engine speed, fuel consumption and exhaust emissions, were measured and recorded carefully. BTE and BSFC, along with the combustion and emission parameters, were computed for engine performance. Thereafter, the diesel-PKO biodiesel blends were tested and all the data were recorded for each sample simultaneously. After completing each and every test, the diesel engine was made to continue to operate till the fuel left in the fuel tank was completely drained; then, the subsequent fuel blend was poured.

\subsubsection{Error Analysis and Uncertainty}

Calculating the uncertainty of the equipment employed is a method to get more precise results. Because of environmental and operating conditions, calibration and selection of instrument, instrument quality and test order, etc., the results may vary and the same results could not be obtained. Experiments were iterated three times and the average values were taken for plotting the graph. Table 5 shows the uncertainties, as well as accuracies, of the equipment used in this investigation. The overall uncertainty percentage (in this study, 
$\pm 2.53 \%$ ) was calculated, based on the combined effect caused by the uncertainty of the various measuring instruments and propagation of errors from Holman [24], as follows. Percentage of uncertainty occurring in the experiments $=$ root square of uncertainty of

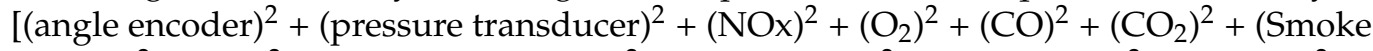
opacity $\left.)^{2}+(\mathrm{HC})^{2}+(\mathrm{K}-2 \text { thermocouple })^{2}+(\text { manometer })^{2}+(\text { stop watch })^{2}+(\text { burette })^{2}\right]=$ root square of $\left[(0.3)^{2}+(0.01)^{2}+(0.5)^{2}+(0.35)^{2}+(0.02)^{2}+(0.2)^{2}+(0.3)^{2}+(1.1)^{2}+(1.5)^{2}+\right.$ $\left.(0.3)^{2}+(1.5)^{2}\right]=$ root square of $(6.393)= \pm 2.53 \%$

Table 5. Instruments uncertainty percentage and accuracy and its measuring range.

\begin{tabular}{|c|c|c|c|c|}
\hline \multicolumn{2}{|c|}{ Instrument } & Percentage Uncertainties & Measuring Range & Accuracy \\
\hline \multicolumn{2}{|c|}{ AVL 3066A02 crank angle encoder } & \pm 0.3 & & \pm 1 \\
\hline \multicolumn{2}{|c|}{ AVL pressure transducer GH12D } & \pm 0.01 & $0-250$ bar & \pm 0.01 bar \\
\hline \multirow{5}{*}{$\begin{array}{l}\text { AVL DI GAS } 444 \text { N } \\
\text { (five gas analyzer) }\end{array}$} & $\mathrm{NOx}$ & \pm 0.5 & 0-5000 ppm vol & 1 ppm vol \\
\hline & $\mathrm{O}_{2}$ & \pm 0.35 & $0-25 \%$ vol & $0.01 \% \mathrm{vol}$ \\
\hline & $\mathrm{CO}$ & \pm 0.02 & $0-15 \%$ vol & $0.0001 \mathrm{vol}$ \\
\hline & $\mathrm{HC}$ & $\pm 4 \mathrm{ppm}$ & 0-30,000 ppm vol & $1 \mathrm{ppm} / 10 \mathrm{ppm}$ \\
\hline & $\mathrm{CO}_{2}$ & \pm 0.2 & $0-20 \%$ vol & $0.1 \%$ vol \\
\hline \multirow{4}{*}{ AVL 437C smoke meter } & K-2 thermocouple & \pm 0.3 & $\left(0-1250^{\circ} \mathrm{C}\right)$ & $\pm 1{ }^{\circ} \mathrm{C}$ \\
\hline & Smoke intensity & \pm 1.1 & $0-100 \%$ & $\pm 1 \%$ \\
\hline & U-tube manometer & \pm 1.5 & & $\pm 1 \mathrm{~mm}$ \\
\hline & Digital stopwatch & \pm 0.3 & & $\pm 0.2 \mathrm{~s}$ \\
\hline \multicolumn{2}{|c|}{ Burette } & \pm 1.5 & $1-30 \mathrm{cc}$ & $\pm 0.2 \mathrm{cc}$ \\
\hline
\end{tabular}

\section{Results and Discussions}

\subsection{Optimization of Biodiesel Production}

The influence of various alcohol ratios (3:1, 6:1, 9:1), i.e., molar ratio using two different catalysts $(\mathrm{KOH}$ and $\mathrm{NaOH})$, with 3 different reaction temperatures $\left(50,55,60^{\circ} \mathrm{C}\right)$ for a time of $45 \mathrm{~min}$, on the production of PKO biodiesel yield (\%) were experimentally investigated (Figure $4 a, b$ ) and validated using the MINITAB-17 software (Figure 5). The results of both experimental results and predicted values by the model proposed are tabulated in Table 3.

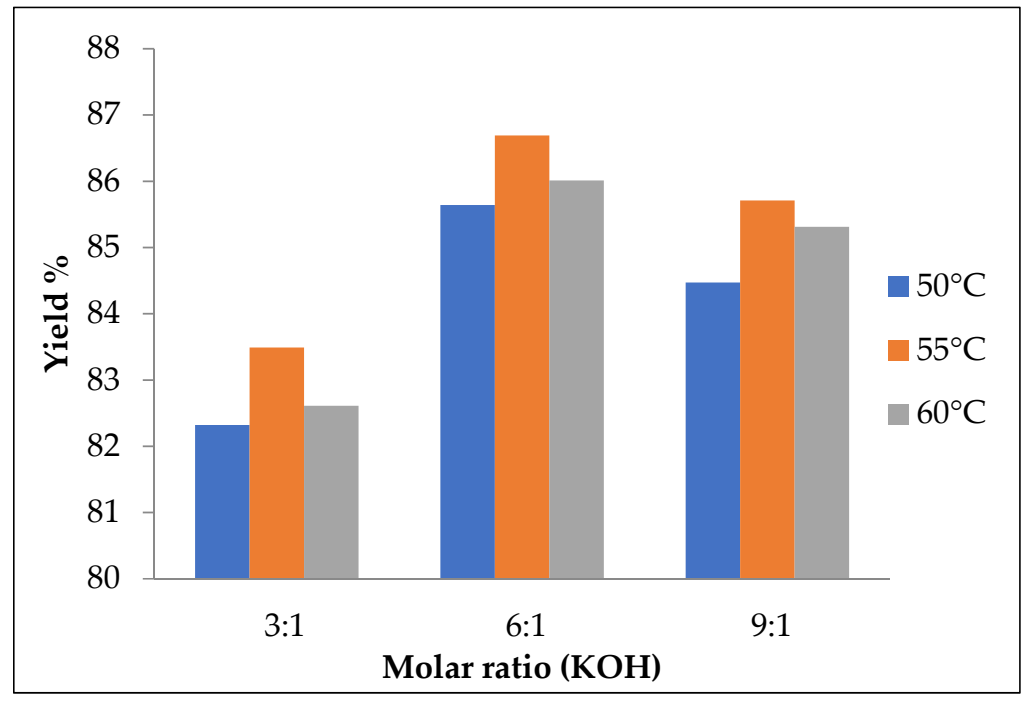

(a)

Figure 4. Cont. 


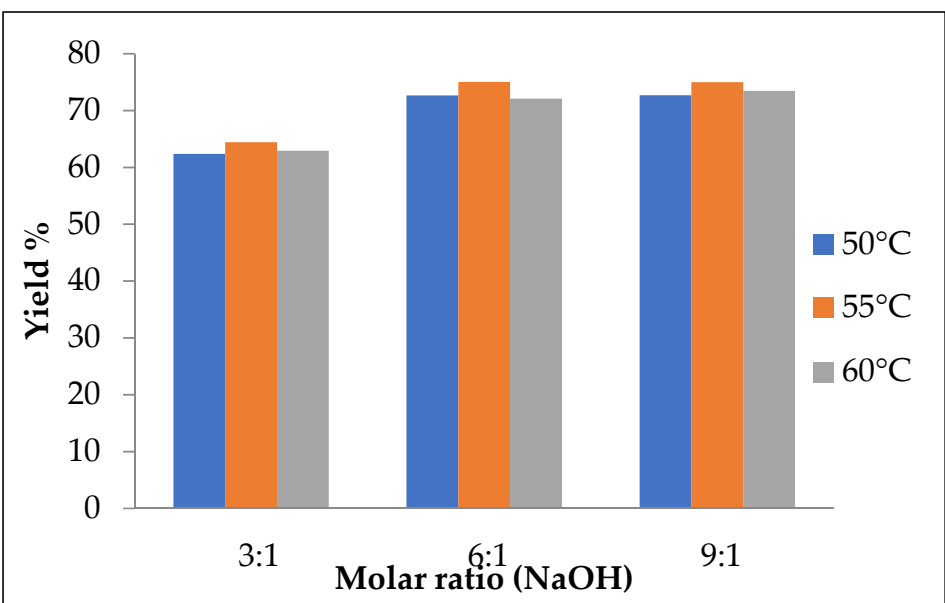

(b)

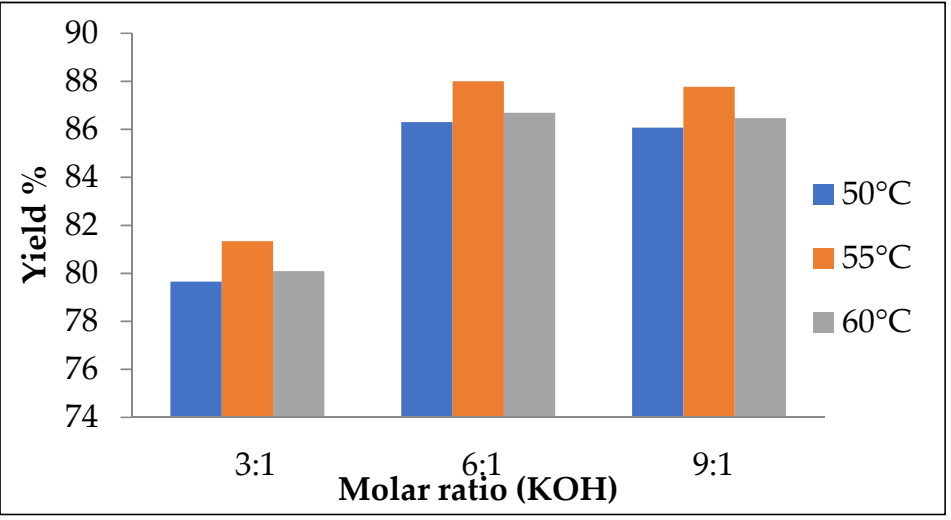

(c)

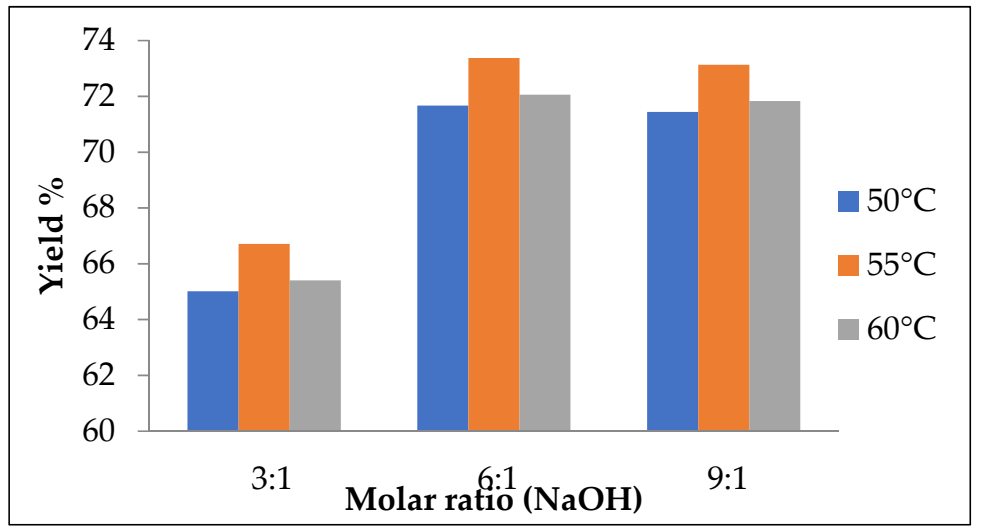

(d)

Figure 4. (a) Experimental results using the $\mathrm{KOH}$ catalyst. (b) Experimental results using the $\mathrm{NaOH}$ catalyst. (c) Modeling results using the $\mathrm{KOH}$ catalyst. (d) Modeling results using the $\mathrm{NaOH}$ catalyst. 


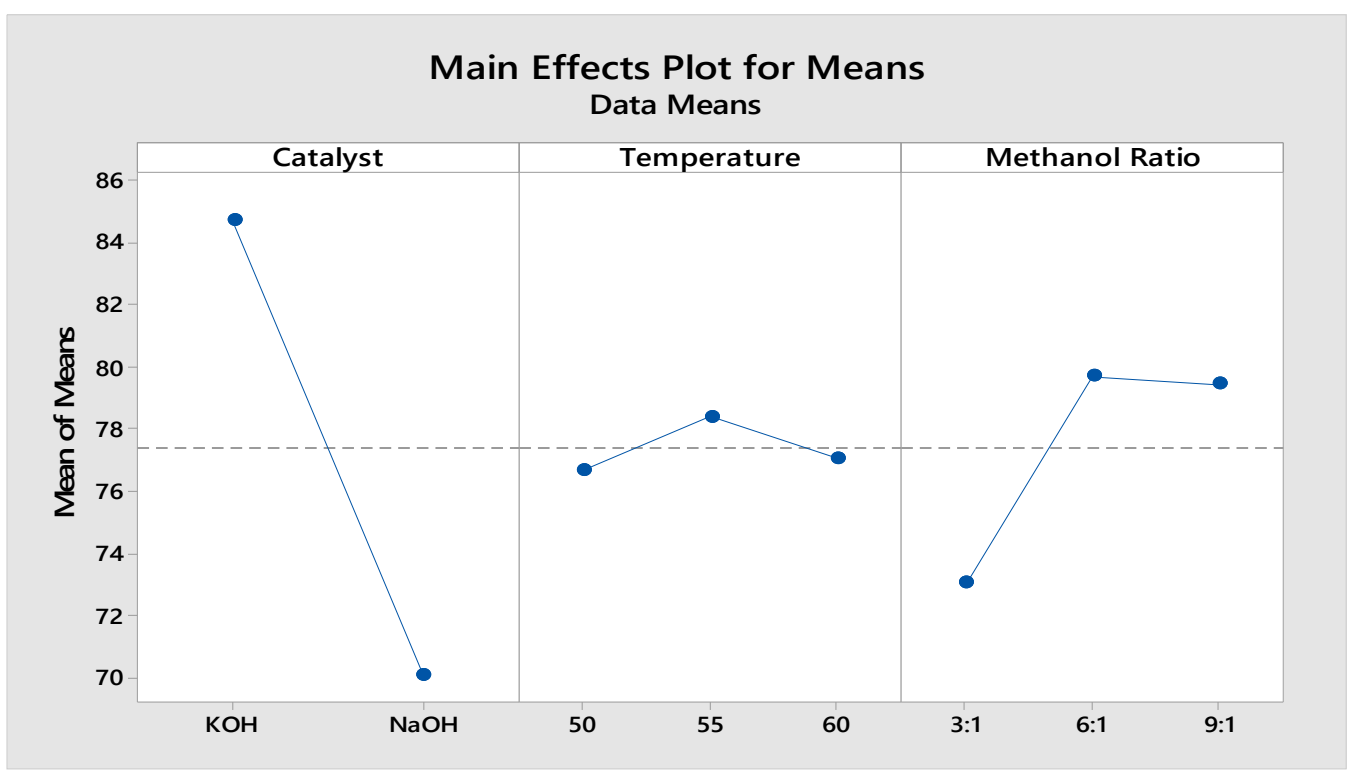

Figure 5. Plot of model experiment: means versus catalyst, temperature and methanol ratio.

\subsubsection{Effect of Different Ratios of Molar Ratio on PKO Biodiesel Yield}

Figure $4 \mathrm{a}, \mathrm{b}$ depict the obtained PKO biodiesel yield for different molar methanol-to-oil ratios for a reaction time of $45 \mathrm{~min}$, using $\mathrm{KOH}$ and $\mathrm{NaOH}$ as catalyst, with 3 different temperatures $\left(50,55\right.$ and $60^{\circ} \mathrm{C}$ ). For the molar ratio of 3:1, the biodiesel yield for both $\mathrm{KOH}$ and $\mathrm{NaOH}$ catalysts was lower, due to the insufficient methanol level in the oil for the reaction. The maximum yield of PKO biodiesel was obtained at the molar ratio of 6:1 with the temperature of $55^{\circ} \mathrm{C}$ (Table 3 ) for the $\mathrm{KOH}(86.69 \%)$ and $\mathrm{NaOH}(75.21 \%)$ catalysts. From the results, the biodiesel conversion was more effective in the methanol level of $6: 1$, as can be also observed from the Figure 4. The biodiesel conversion was decreased with further increase in the molar ratio (i.e., 9:1), probably because of the fact that glycerol separation from biodiesel fraction is very hard. This is due to the high glycerine solubility that affects the settling of glycerine, thereby decreasing the biodiesel yield [25]. It is observed, from Figure 4, that the $\mathrm{KOH}$ catalyst had a higher biodiesel yield, compared to the $\mathrm{NaOH}$ catalyst, due to the higher glycerol separation.

\subsubsection{Effect of Different Catalysts on the Biodiesel Yield}

The amount of catalyst loading on the molar ratio influences the production of biodiesel by accelerating the reaction rate. The amounts of catalyst required for $\mathrm{KOH}$, based on FFA values, were 1.067, 1.152 and $1.408 \mathrm{~g}$ at the molar ratios of 3:1, 6:1 and 9:1, respectively, whereas the amounts for the $\mathrm{NaOH}$ catalyst were $1.152,1.195$ and $1.707 \mathrm{~g}$ at the molar ratios of 3:1, 6:1 and 9:1. As observed in Table 3, $\mathrm{KOH}$ and $\mathrm{NaOH}$ influence the biodiesel production yield. The maximum PKO to biodiesel conversion (86.69\%) for the catalyst $\mathrm{KOH}$ was obtained at the conditions of molar ratio of $6: 1$, temperature of $55^{\circ} \mathrm{C}$ and time of $45 \mathrm{~min}$. The biodiesel production was decreased by increasing catalyst concentration over the molar ratio. This might be due to the stable emulsion created because of the glycerine interaction with the excess methanol, which affects the settling of glycerine [25]. For the $\mathrm{NaOH}$ catalyst, the maximum biodiesel yield from $\mathrm{PKO}$ was obtained at the molar ratio of $6: 1$, temperature of $55^{\circ} \mathrm{C}$ and reaction time of $45 \mathrm{~min}$. At higher molar ratio, higher amount of the $\mathrm{NaOH}$ catalyst decreased the biodiesel yield. The reason might be because of soap formation during the reaction, which results in product losses [25]. Additionally, the biodiesel yield decreased, with the $\mathrm{NaOH}$ catalyst, due to greater water formation during the reaction. From Figure 4a,b, the biodiesel conversion yield was higher with $\mathrm{KOH}$, 
compared to the $\mathrm{NaOH}$ catalyst. $\mathrm{KOH}$ could lead to $15.5 \%$ higher biodiesel yield than the $\mathrm{NaOH}$ catalyst at the molar ratio of $6: 1$, whereas, at the ratio of $3: 1$, the difference was $29.57 \%$.

\subsubsection{Effect of Temperature on the Yield of Biodiesel Production}

Various reaction temperatures, such as 50,55 and $60^{\circ} \mathrm{C}$, were studied in the present investigation. Maximum PKO biodiesel yield was found at the temperature of $55^{\circ} \mathrm{C}$ for both catalysts, due to maximum methanol diffusivity in the oil which leads to collisions among molecules, thereby allowing glycerine to settle, as observed in Figure 4. With temperature rising to $60^{\circ} \mathrm{C}$, the biodiesel yield decreased slightly, due to the evaporation of the methanol [25]. In addition, higher temperature increases saponification, compared to the transesterification reaction.

\subsubsection{Linear Model Analysis}

The regression coefficient yield of PKO biodiesel was determined using the MINITAB17 software, using the full quadratic the model proposed given in Equation (4). The values of the coefficient and adjusted coefficient $\left(R^{2}\right.$ and $R^{2}$ adj.) were $95.13 \%$ and $93.10 \%$, respectively. Since $R^{2}$ is close to $95 \%$ the null hypotenuse is proven and the values are verified. From Table 3, the model proposed biodiesel yield variations almost matched the experimental biodiesel yield ones. The optimum condition of the model yield was $88 \%$ for biodiesel yield in the conditions of $1 \mathrm{wt} . \% \mathrm{KOH}$ catalyst, $6: 1 \mathrm{molar}$ ratio and at $55{ }^{\circ} \mathrm{C}$ temperature, as presented Figure 4c,d whereas the optimum condition for the experimental biodiesel yield was $87 \%$. This shows the fully quadratic the model proposed for prediction of the biodiesel yield was highly reliable.

Biodiesel yield $(\%)=93.58+3.558(\mathrm{MR})+1.750(\mathrm{C})+2.589(\mathrm{~T})-0.33\left(\mathrm{MR}^{2}\right)-2.800\left(\mathrm{C}^{2}\right)-1.280\left(\mathrm{~T}^{2}\right)$
$+0.238(\mathrm{MR} \times \mathrm{C})+0.008(\mathrm{MR} \times \mathrm{T})+0.66(\mathrm{MR} \times \mathrm{T})+0.192(\mathrm{C} \times \mathrm{T})-1.6(\mathrm{C} \times \mathrm{T})-0.175(\mathrm{P} \times \mathrm{T})$

\subsection{Combustion Characteristics}

The performance and emissions of different blends of diesel-PKO biodiesel blends (B0, B100, B20, B30 and B40), B20 + DEE and B20 + BHT, which were tested in a single-cylinder, 4-stroke DI diesel engine at a constant speed of $1500 \mathrm{rpm}$ at various load conditions, are presented in this section. The discussed combustion and performance parameters are HRR, in-cylinder pressure, BTE and BSFC and the discussed exhaust emission are CO, NOx, HC, EGT and smoke opacity.

\subsubsection{Heat Release Rate}

Figure 6 shows the variations in HRR of different diesel-PKO biodiesel blends. HRR is an important parameter which gives in-depth information about the burning characteristics and provides a way to calculate the combustion duration. Actually, in the DI diesel engine, during combustion, the heat release happens in two phases. The premixed combustion (PC) phase is the first phase; after the injection starts, the air/fuel-rich mixture is formed because of the delay in ignition where the pressure is raised. The HRR also gives indepth information about the SOC, which was occurred at $12-13^{\circ}$ before top dead center (BTDC) for all fuel tested. If fact, when the piston reaches near the TDC, the vaporization of fuel occurs, due to the high pressure and temperature. Because of the ignition delay, which causes a negative heat release, once the ignition starts, the heat release momentarily changes to positive. Once the combustion starts, the fuel-rich mixture burns rapidly and uncontrolled combustion occurs, where the heat release is at its maximum. The diffusion combustion (DC) phase is the second phase. In the diffusion phase of combustion process, improved mixing of the air and fuel takes place after the oxygen is consumed. This results in controlled combustion which happened at up to $18^{\circ}$ after top dead center (ATDC). Then, the progressive burning happens at up to $45^{\circ} \mathrm{ATDC}$ and also the peak heat release occurred between $-6^{\circ}$ BTDC to $8^{\circ}$ ATDC (as shown in Figure 5). These values, for B100, B0, B20, B30, B40, B20 + BHT and B20 + DEE, were 52.67, 72.68, 67.38, 65.35, 64.64, 66.03 and $70.75 \mathrm{~kJ} / \mathrm{m}^{3}$, 
respectively. The curve of the diesel-PKO biodiesel blends showed the same pattern of heat release, irrespective of the applied loads [14]. The HRR for diesel was comparable to the B20, B30 and B100 PKO biodiesel blends. The B20 fuel blend recorded the second highest HHR due to better atomization of its low viscosity [26]. Results show that the B20BHT fuel blend showed $2 \%$ reduction in HHR $\left(66.03 \mathrm{~kJ} / \mathrm{m}^{3}\right)$, compared with the B20 fuel blend, which could be due to the low level of oxygen content, whereas, the HRR of B20DEE increased by $4.7 \%,\left(70.75 \mathrm{~kJ} / \mathrm{m}^{3}\right)$ compared to the B20 fuel blend-this was almost close to that of diesel fuel. This result is in agreement with Imtenan et al. [21], who justified that the better atomization and fuel bound $\mathrm{O}_{2}$ content of DEE lead to complete burning, thereby increasing the HRR. However, late SOC was observed for the B20DEE blend, compared with the B20 blend (despite its higher cetane number), as shown in Figure 6. This could be because of higher vaporization of latent heat of DEE in the B20 blend, which causes injection into the low temperature zone $[27,28]$.

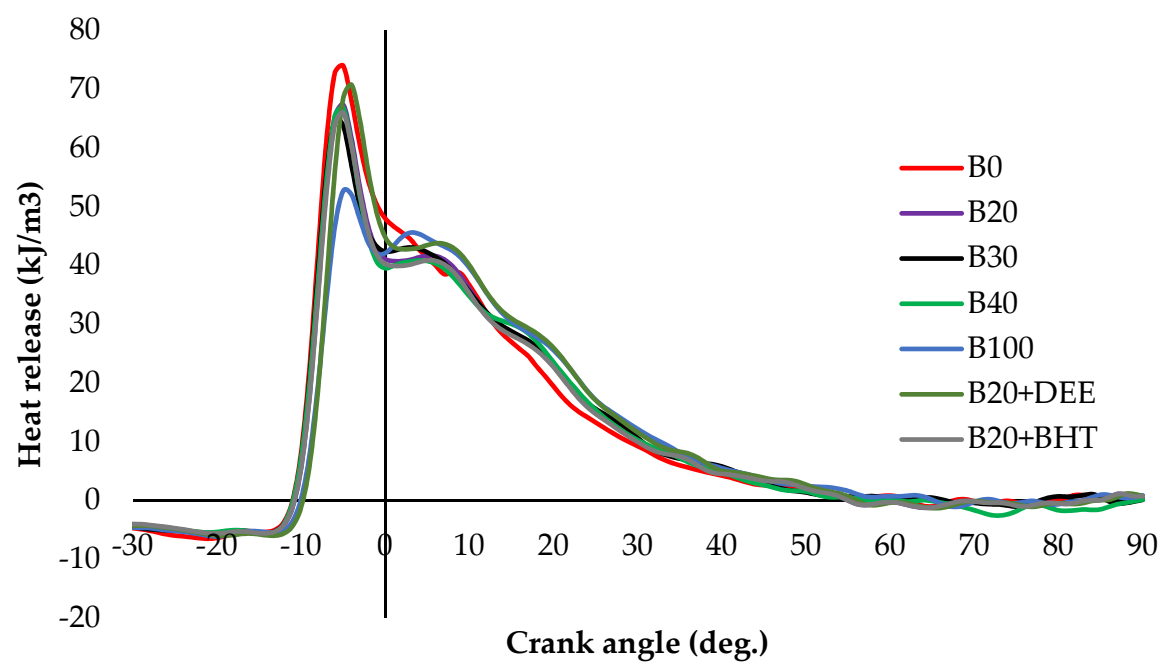

Figure 6. HRRs of all fuel blends at full load.

\subsubsection{Cylinder Pressure}

Figure 7 depicts the in-cylinder pressure at full load condition of all fuel blends samples versus crank angle. Results show that the peak cylinder pressure of all fuel samples, B100, B0, B20, B30, B40, B20BHT, and B20DEE, happened within the range of $4-8^{\circ}$ ATDC and was $69.04,73.49,72.73,70.96,70.12,70.75$ and 73.27 bar, respectively. The peak pressure rise showed similar patterns for all the fuels. The highest cylinder pressure (73.49 bar) was recorded for diesel fuel due to its high calorific value. The next highest pressure was obtained for the B20 fuel blend, at 72.73 bar, which was very close to that of diesel fuel. Among all the fuel samples, the lowest in-cylinder pressure was measured for B100, which could be due to the lower volatility and greater viscosity, which consequently leads to the low air-to-fuel mixture in the premixed burning zone, compared to diesel fuel [26]. Lower cylinder pressure was previously reported for biodiesel combustion compared to diesel fuel [29]. In addition, Elkelawy et al. [30] argued that this is because of the low self-ignition characteristics and heating contents of the biodiesel fuel, relative to diesel fuel [31]. The effect of adding the DEE additive into the B20 fuel blend slightly increased in-cylinder pressure by $1 \%$, compared to B20. This could be attributed to the increased $\mathrm{O}_{2}$ content of the blend. The in-cylinder pressure of the B20DEE blend was slightly greater than that of the B20 blend, but lesser than that of diesel, probably due to the higher evaporation rate of DEE, resulting in lower cylinder temperature [16]. When adding BHT into B20, the pressure of the cylinder was reduced, compared with the B20 blend, due to the partial burning, because the BHT antioxidant reduces carbon oxidation (i.e., the $\mathrm{OH}$ radicals that participate in the combustion) by scavenging the $\mathrm{OH}$ radicals [17]. 


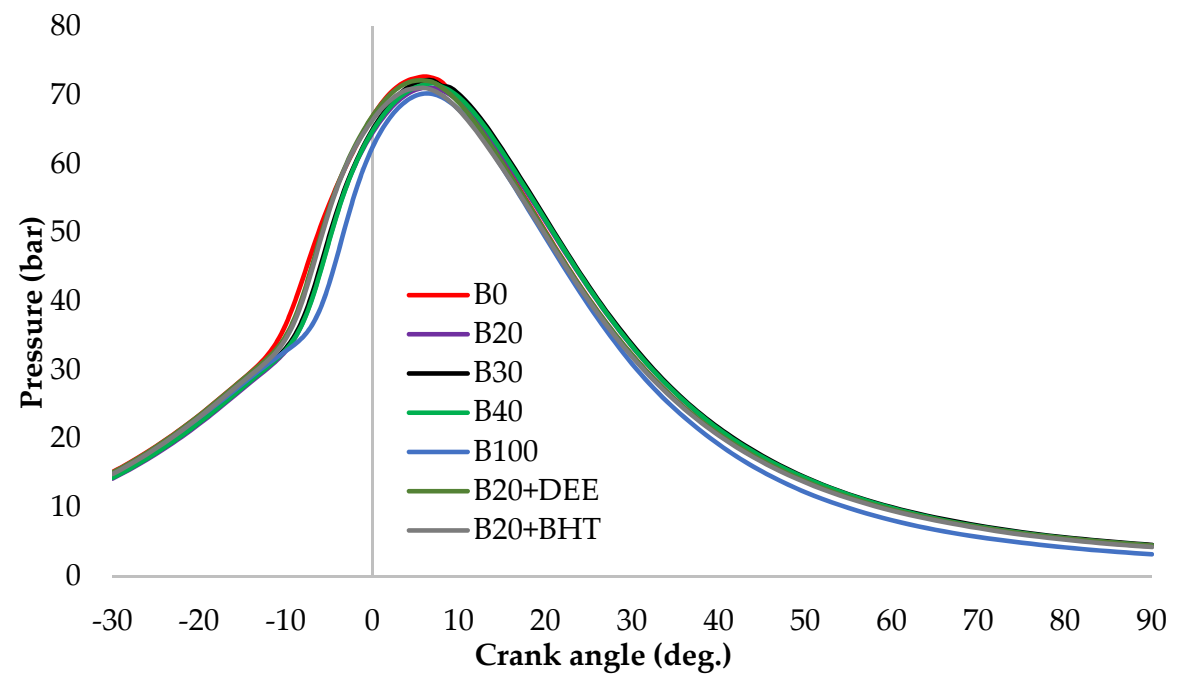

Figure 7. In-cylinder pressure for all fuel blends at full load.

\subsection{Performance Analysis}

\subsubsection{Brake Thermal Efficiency (BTE)}

Figure 8 depicts the BTE of all tested fuel blends at various load conditions. BTE can be determined between the brake power output and the combustion fuel energy, which is one of the very important factors that tell us how expeditiously the heat energy is exchanged into effective work [32]. Brake thermal efficiency increased gradually with the load for all the fuel blends. As shown in Figure 8, diesel fuel recorded the maximum BTE, while the least BTE was found for B100 at 100\% load. There are several reasons for this finding, such as higher viscosity $\left(4.2 \mathrm{~mm}^{2} / \mathrm{s}\right)$, lower heating content and lower air-fuel mixing of biodiesel fuel [33]. The results show that the BHT additive could improve BTE at full load by $6.64 \%$ and $4.6 \%$, compared to neat diesel and B20, respectively. Like all oxygenated additives, addition of DEE into the B20, resulted in higher BTE, compared to diesel and other blends of PKO biodiesel. The BTE increment of the B20DEE fuel blend was 5.4\% and $3.38 \%$ more than $\mathrm{B} 20$ and diesel fuel, respectively. The reason might be due to the higher oxygen content of DEE, which contains $21.6 \% \mathrm{O}_{2}$ in their molecule structure, and also to its low viscosity [27]. Increased BTE after adding oxygenated additive was reported by Ren et al., who examined several different oxygenated additives and observed that they could improve BTE generally [34].

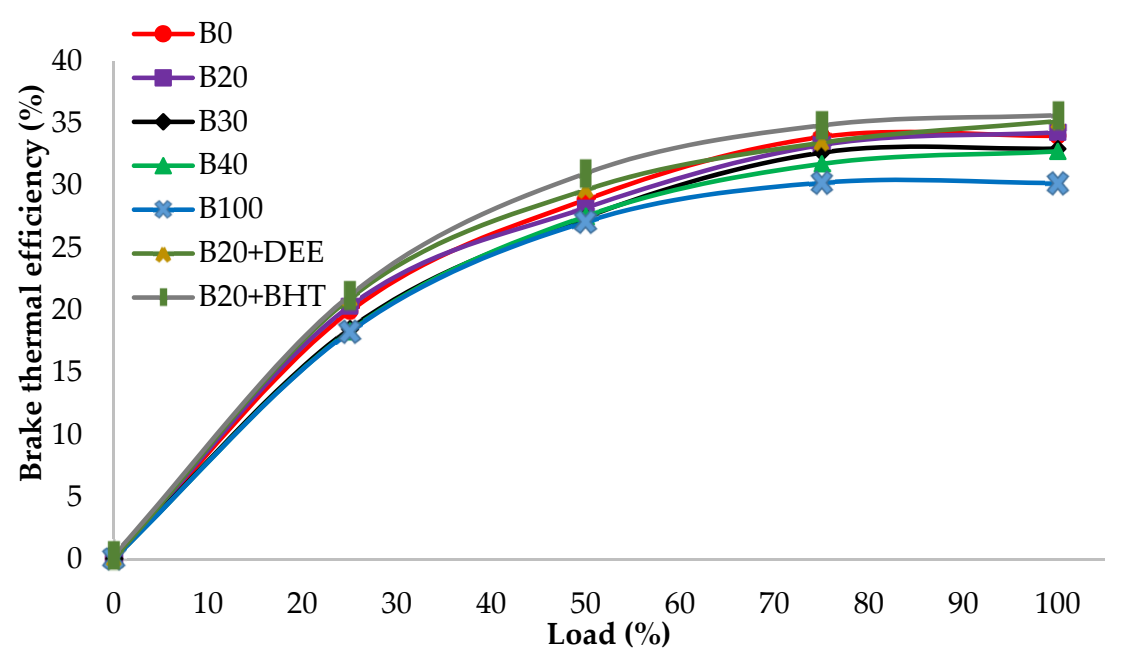

Figure 8. BTE of all fuel blends at different engine loads. 


\subsubsection{Brake Specific Fuel Consumption}

BSFC is the mass rate of consumption of fuel per unit brake power, which is reciprocally proportional to BTE. Figure 9 shows the variation in BSFC of different fuel samples at constant engine speed and various load conditions. BSFC decreased with load increase, regardless of the fuel types [2,35]. Biodiesel showed an increase in BSFC, compared to diesel fuel. Tompkins et al. [36] argued that this is due to some reasons, such as higher viscosity, incomplete fuel burning and low $\mathrm{CV}$ of biodiesel fuel. These reasons are emphasized by other researchers $[37,38]$. At 100\% load, B100 depicted the highest value, $0.31 \mathrm{~kg} / \mathrm{kWh}$ of BSFC. On the other hand, diesel fuel recorded the lowest BSFC at $0.23 \mathrm{~kg} / \mathrm{kWh}$. However, the B20 fuel blend values were almost close to the diesel fuel ones at all type of loads [26]. After adding an oxygenated additive, the BSFC decreased, for the B20DEE fuel blend, by $0.25 \mathrm{~kg} / \mathrm{kWh}$, which was $3.84 \%$ lower than the B20 fuel blend. High fuel-bound oxygen content is the main reason which helps the DEE + B20 fuel blend to have better combustion efficiency. At low loads, the BSFC for DEE and diesel fuel was similar in value, probably due to the lower heat loss [17]. The effect of the BHT antioxidant additive recorded a BSFC of $0.24 \mathrm{~kg} / \mathrm{kWh}$, which was less than other diesel-biodiesel blends. However, this value was $7.69 \%$ lower than that of the B20 fuel blend and almost close to the diesel fuel one at full load. Similar results were reported by Vijay Kumar et al. for DEE combustion [39]. In addition, Kumar et al. reported that the addition of palm oil methyl ester into diesel fuel led to an increase in BSFC [40].

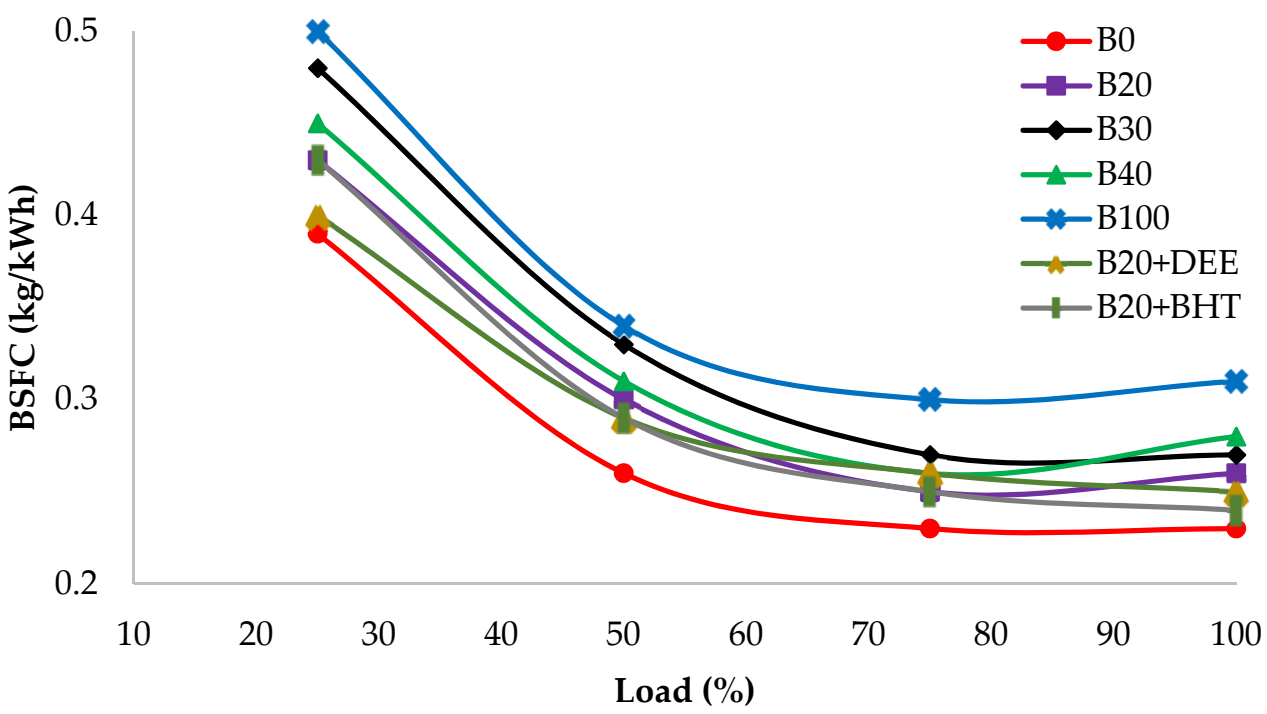

Figure 9. BSFC of all fuel blends at different engine loads.

\subsection{Emission Characteristics}

\subsubsection{Nitrogen Oxides (NOx)}

The NOx emission of all fuel tested at different loads are shown in Figure 10. NOx emissions increased steadily with load for all experimented fuel blends. NOx emission is formed through oxidation of nitrogen at high temperatures in the combustion chamber [31,41]. Therefore, NOx emission was at peak at full load compared to the low loads, because of higher flame temperature at higher loads [32].

From Figure 10, the results indicate that B20, B30 and B40 had a higher NOx emission than diesel fuel. This could be attributed to the biodiesel high molecule weight and also to the presence of high oxygen content, which increases the temperature locally, resulting in higher emissions of NOx [31,35]. The values of NOx emission of B100, B0, B20, B30, B40, B20BHT and B20DEE were 1714, 1855, 1879, 1886, 1796, 1494 and 1583 ppm, respectively. For the B20 blend, the NOx emission was slightly greater than diesel by $1.3 \%$, whereas the NOx emission of B100 was 7.6\% less than diesel fuel. The presence of DEE in B20 
decreased NOx emission by $14.6 \%$, compared to diesel fuel. This could be well justified by the higher latent heat of evaporation, which decreased the premixed combustion part, thereby resulting in combustion temperature reduction [17]. Among all fuel blends, the B20BHT fuel blend was found to have the lowest NOx emission, which was $19.4 \%$ less than that of diesel fuel. This could be due to the lower oxygen content, which leads to a decrease in cylinder combustion temperature [14]. In addition, BHT reduces free radicals formation, which subsequently results in lower NOx emissions [42].

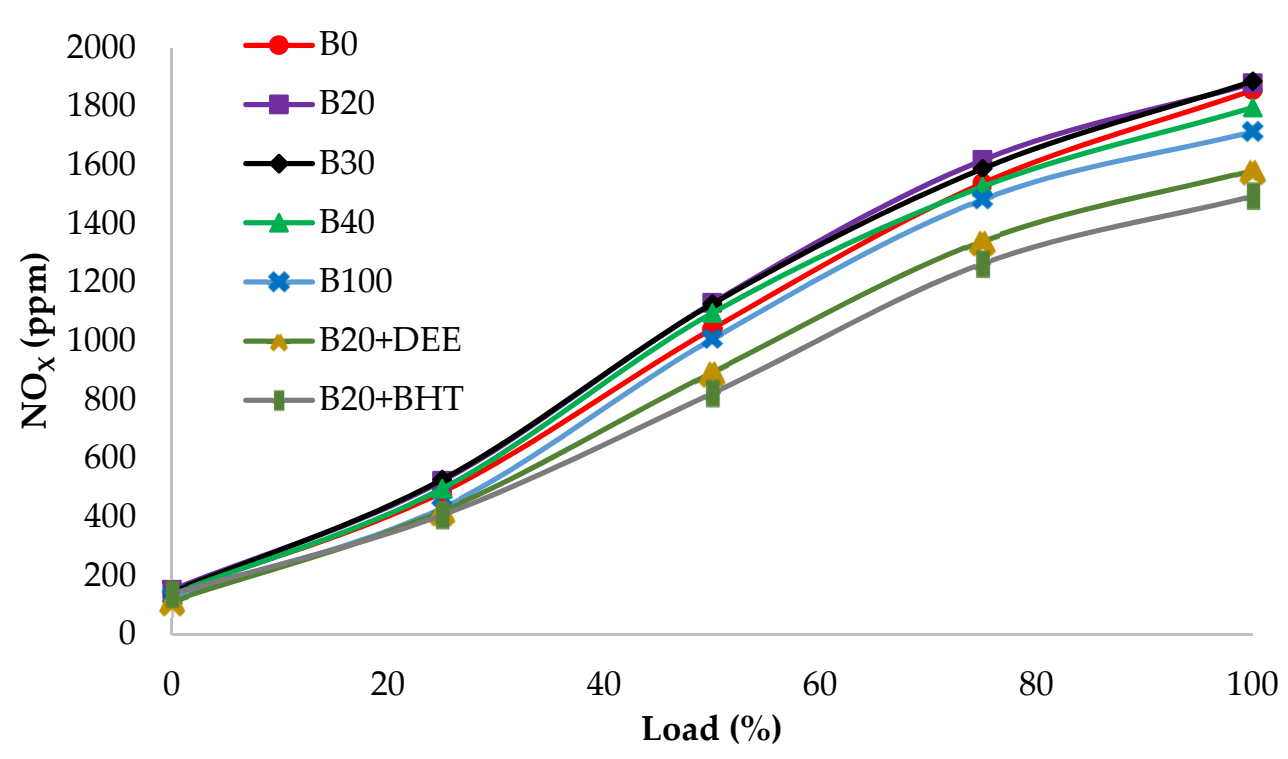

Figure 10. NOx emission of all fuel blends at different engine loads.

\subsubsection{Carbon Monoxide (CO)}

Figure 11 shows the $\mathrm{CO}$ emissions of different fuel blends at various loads. Carbon monoxide emission is mainly formed because of insufficient oxygen in the air/fuel mixture. $\mathrm{CO}$ emission results do not show significant variation at lower loads. However, at full load, rich fuel zones cause the incomplete combustion and $\mathrm{CO}$ emission drastically increases [43].

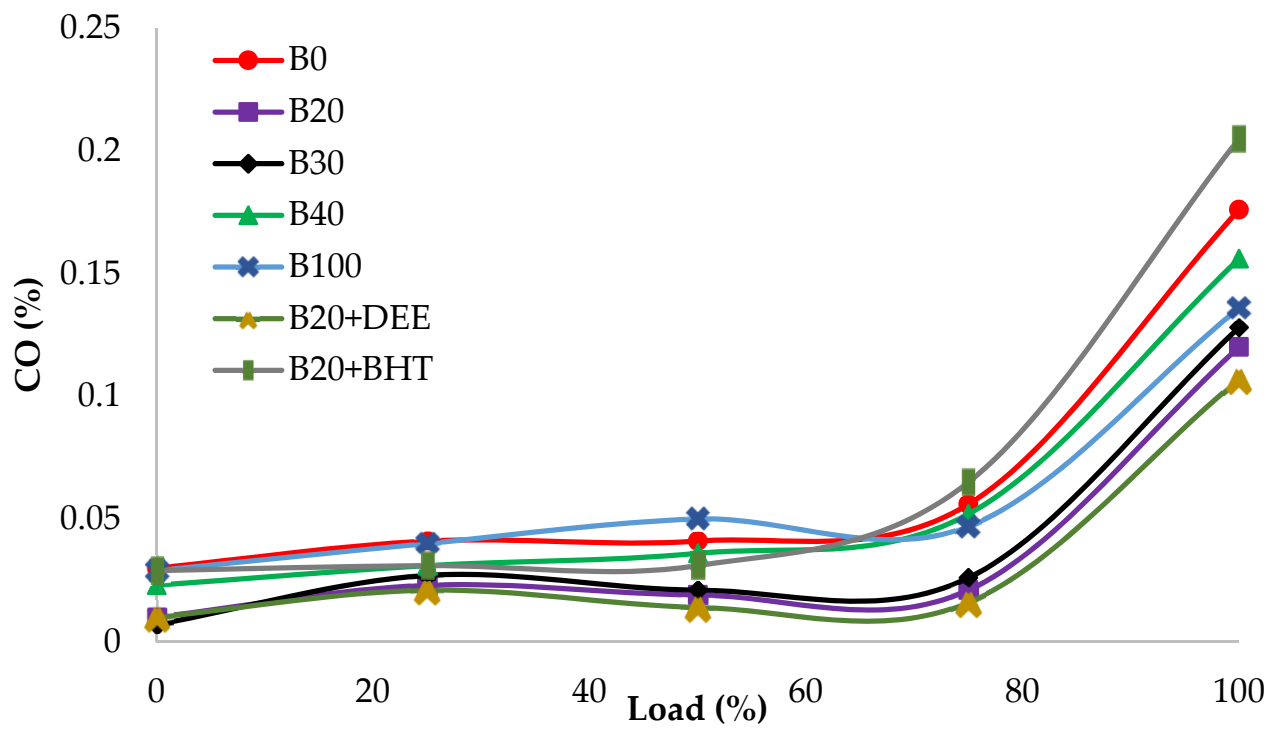

Figure 11. CO emissions of all fuel blends at different engine loads. 
The measured values of CO emission for the fuel blends B100, B0, B20, B30, B40, B20 + BHT and B20 + DEE were 0.136, 0.176, 0.120, 0.128, 0.156, 0.205 and 0.107\%, respectively. CO emission for all diesel-PKO biodiesel blends had minimum values, compared to the diesel fuel. This could be due to the high oxygen content, which provides more complete burning $[1,44]$. However, diesel had the highest $\mathrm{CO}$ emission $(0.176 \%)$, compared to the blends of PKO biodiesel. CO emission of the B20 fuel blend does not show remarkable difference with diesel fuel (i.e., 0.12\%). B100 and B40 recorded 11.7\% and $23 \%$ higher $\mathrm{CO}$ emission than the B20 blend, but the measured value was less than that of diesel fuel [14]. The influence of DEE being added to B20 decreased CO emission by $10.8 \%$ and $39.2 \%$, compared to B20 and diesel fuel, due to the higher amount of fuel bound oxygen content, which increases complete combustion even in locally rich fuel zones and subsequently leads more CO oxidation [17]. The high evaporation rate of DEE shortens the spray penetration length, thereby decreasing CO emissions [19]. As expected, the addition of the BHT antioxidant into B20 increased CO emissions by $14.14 \%$, compared to diesel. Antioxidants have a high impact on scavenging $\mathrm{OH}$ radicals, which is directly related to the oxidation of $\mathrm{CO}$ to $\mathrm{CO}_{2}$ [42].

\subsubsection{Hydrocarbon (HC)}

Figure 12 depicts the unburnt $\mathrm{HC}$ emissions of all tested samples at various engine loads. The main reason of HC emission formation is the poor dissipation of fuel in the rich fuel zones, which causes the partial or incomplete combustion. From the other side, in the lean air/fuel mixture it causes low cylinder temperature. In addition, HC emission is also due to the a thin layer of fuel on the combustion chamber wall, which are due to fuel impingement during over spray [30,38,45]. Furthermore, the trapping of fuel in the combustion chamber of crevice areas is also considered as one of the major factors for the increase in $\mathrm{HC}$ emissions [43].

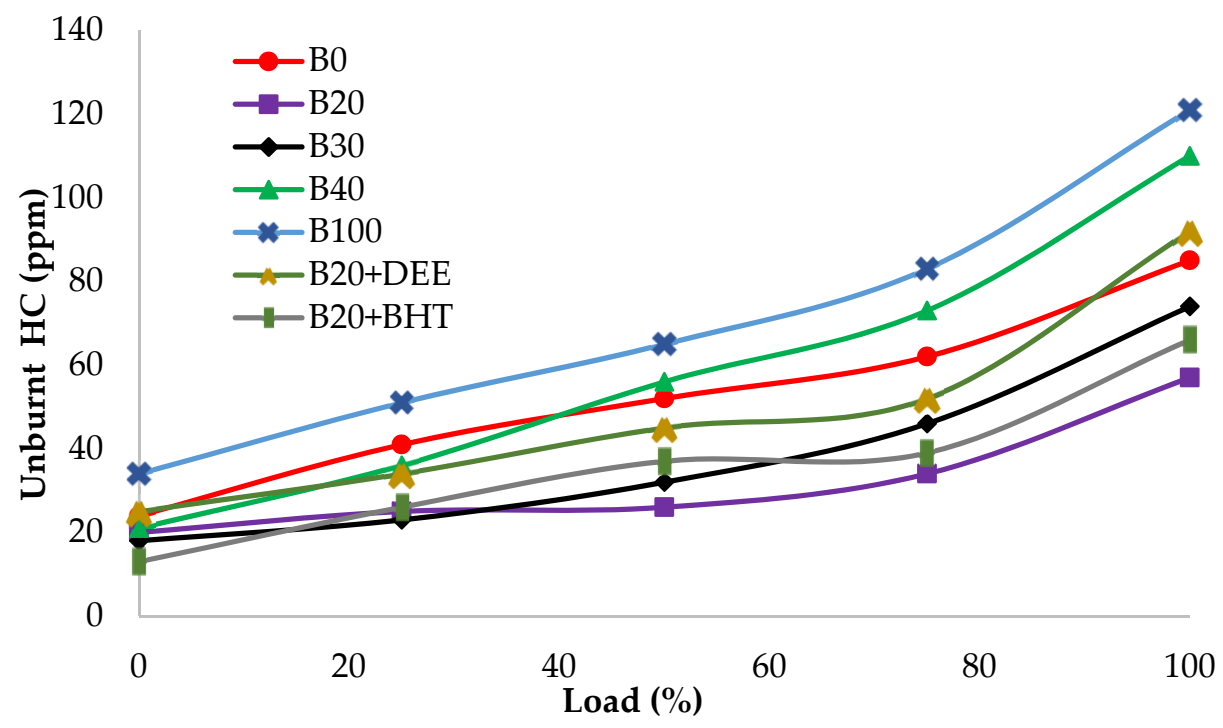

Figure 12. HC emissions of all fuel blends at different engine loads.

All the fuel blends showed a steady increasing of $\mathrm{HC}$ emissions with load. The values of HC emissions for the different fuel tested, B100, B0, B20, B30, B40, B20BHT and B20DEE, were 121, 85, 57, 74, 110, 66 and 92 ppm, respectively. B40 and B100 had greater HC emission values, compared to diesel fuel, due to poor fuel dissipation in rich mixture zones, causing incomplete combustion because of the higher viscosity of biodiesel fuel [42,46]. Heywood has mentioned that higher fuel viscosity has important influence on the atomization of the fuel and, subsequently, the SOC, in the fuel burning process [20]. The HC emission was significantly decreased, for the B20 blend, by 32.9\%, compared to diesel fuel. This could be attributed to the effective participation of oxygen molecules in the burning process, which 
leads to improved combustion quality [41,47]. On the contrary, the addition of additives to the B20 fuel blend showed increased emissions of $\mathrm{HC}$, compared to the B20 fuel blend. At full load, the HC emission of the B20 + DEE blend was measured to be $38 \%$ higher than the B20 fuel blend. Apart from the higher oxygen content of DEE, the reason for the increase in $\mathrm{HC}$ emission of DEE blended in B20 might be the higher heat of evaporation rate, leans the outer part of the flame in the excess rich fuel zone in comparison with over-mixing of fuel with air. At higher loads, excess rich air-fuel ratio during combustion is a common phenomenon, which happens especially with oxygenated additives, such as DEE, which has low density and viscosity [27]. It is evident, from Figure 12, that, in the case of addition of 2000 ppm BHT antioxidant to the B20 fuel blend, HC emission was increased by $13.6 \%$, compared to the $\mathrm{B} 20$ one. The reason for this increment is the negative effect of BHT on the oxidation of oxygen, which results in higher HC emissions [42].

\subsubsection{Smoke Opacity}

Smoke opacity is the measure of particulate emission (i.e., soot content) in the exhaust gas of a diesel engine. Smoke is mainly formed by incomplete fuel combustion because of variations in the operating conditions of the engine [48]. Smoke emission variations of all experimented fuel samples at various loads are depicted in Figure 13. The peak values of smoke emission, which were recorded at engine full load for B100, B0, B20, B30, B40, B20BHT and B20DEE, were 87, 78, 73, 81, 83, 66 and 69\%, respectively. The smoke emission of all diesel-PKO biodiesel blends, except B20, were higher than those measured for diesel fuel. This is mainly because of poor biodiesel atomization, because of higher biodiesel viscosity which causes low in-cylinder temperature and, subsequently, incomplete combustion [26,49]. The intensity of smoke was increased with the increase in load and maximum values were observed at engine full load. During the combustion at higher engine loads, the thermal cracking of long chain unburned hydrocarbons in the insufficient oxygen happens, which leads to an increase in smoke emission [43].

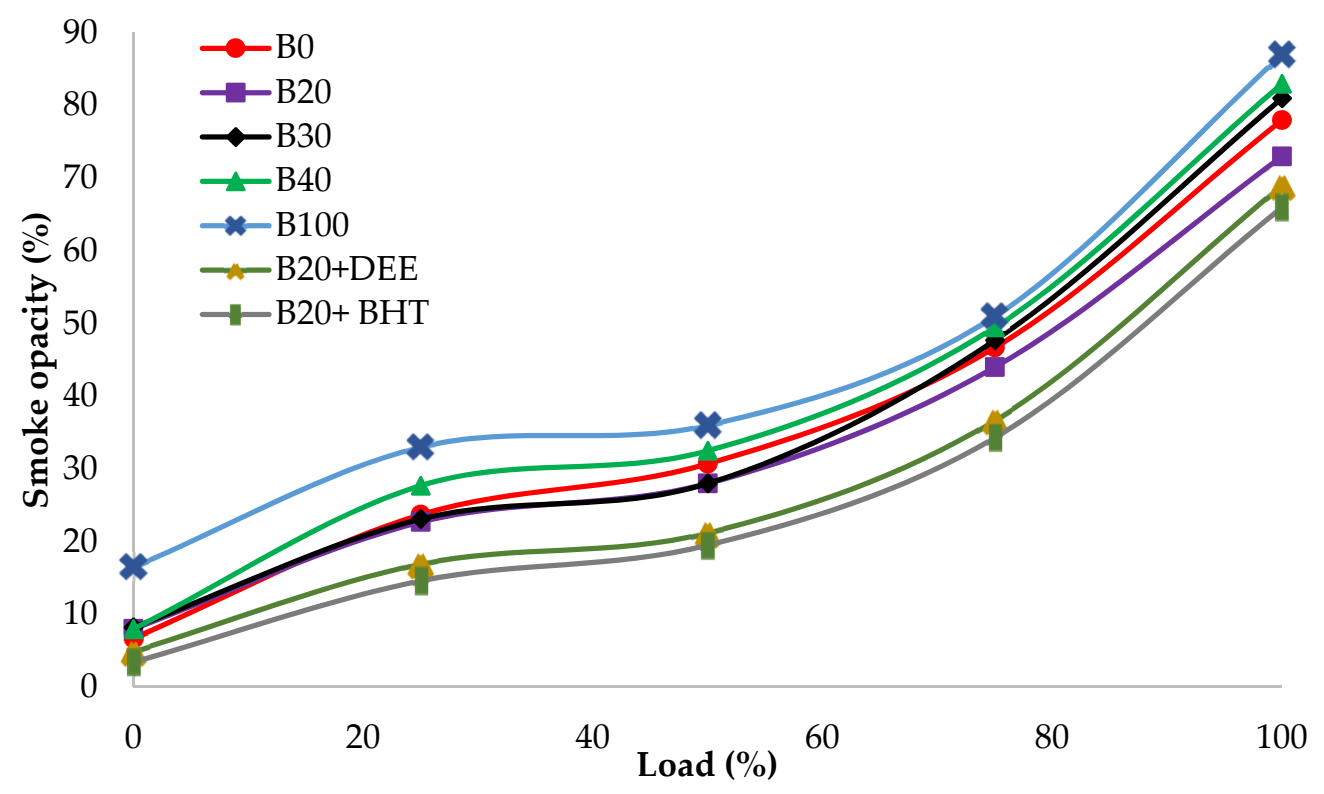

Figure 13. Smoke opacity of all fuel blends at different engine loads.

Smoke emission was significantly decreased for the B20 blend, by $6.4 \%$, compared to diesel fuel, which can be justified by the higher amount of oxygen molecules in the fuel rich zones. Generally, soot is formed mostly in the PC phase, where the stoichiometry air/fuel equivalence ratio prevails [35]. It can be seen, from Figure 13, that $5 \%$ DEE gave significantly lower smoke emissions, by $5.4 \%$ and $11.5 \%$, compared to the B20 blend and 
diesel fuel, respectively. The presence of oxygen molecules in the chemical structures of DEE could enhance the quality combustion process [27]. The addition of the BHT antioxidant to the B20 blend also reduced smoke emissions by $9.5 \%$ and $15.4 \%$, compared to the B20 fuel blend and diesel, respectively [14].

\subsection{Energy Analysis}

The energy analysis results of brake power, cooling water, exhaust gas and unaccounted loss for the different fuel tested, B0, B20, B30, B40, B100, B20DEE and B20BHT are shown in Figure 14 at full loading conditions. A total of $33.78 \%$ of the fuel energy was converted into brake power, $19.16 \%$ was lost by the engine to the cooling water, $19.65 \%$ was lost through the exhaust gases and $27.41 \%$ of heat was exhausted by radiation for diesel fuel. Considering other fuels at the same working condition, it is seen that the conversion rate of fuel energy to brake power has a gradually decreasing trend. This ratio is the expression of thermal efficiency and was calculated as $33.27 \%, 32.96 \%, 32.74 \%$ and $30.2 \%$ for B20, B30, B40 and B100, respectively. These results show that operation with biodiesel blends leads to less brake power for the same fuel energy rate, since biodiesel has a lower heating value than diesel. Considering B20DEE and B20BHT, the conversion rates of fuel energy to brake power showed slight increases, compared to diesel fuel, which were $35.15 \%$ and $35.64 \%$, respectively; this might be due to the higher oxygen content of fuel additives in their molecule structure and also to their low viscosity [50-52].

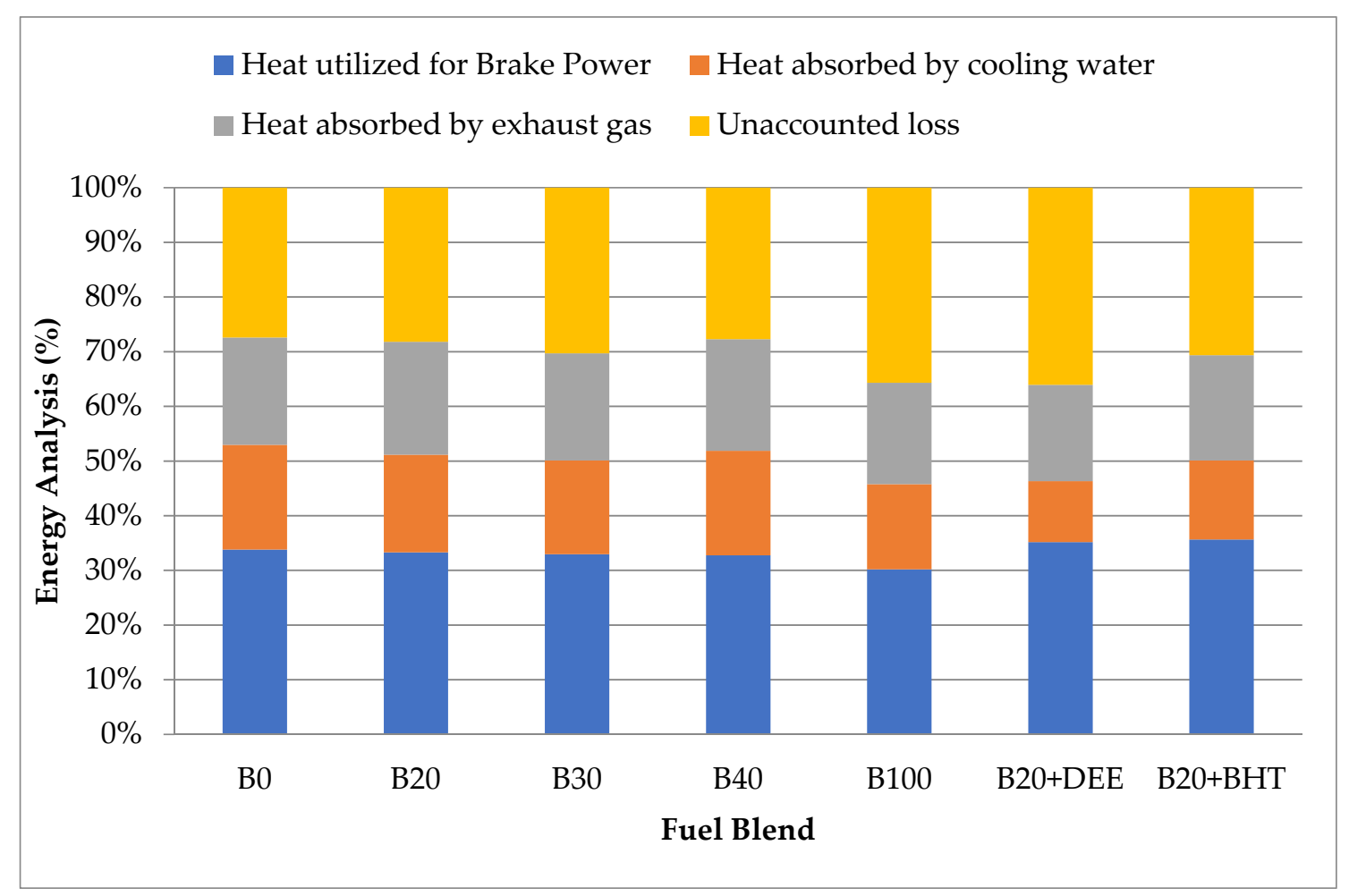

Figure 14. Energy analysis of all fuel blends at maximum engine loads.

\section{Conclusions}

The present research explores the suitableness of diesel-PKO biodiesel blends as substitute fuel in DI diesel engines without any engine modifications. In addition, effects of two additives (DEE and BHT) on B20 were investigated. The optimization of PKO biodiesel production was successfully investigated experimentally and optimum yield conditions were also validated through MINITAB-17 and analyzed using the Taguchi method. The maximum biodiesel yields obtained using the $\mathrm{KOH}$ and $\mathrm{NaOH}$ catalysts were $86.69 \%$ and 
$75.21 \%$, at the molar ratio of $6: 1$ and at the temperature of $55{ }^{\circ} \mathrm{C}$, whereas the simulation designed by the MINITAB- 17 software predicted the yields of $88 \%$ and $73.37 \%$, respectively. Overall, the following conclusions can be drawn from the present study:

- The B20DEE blend attained 4.7\% higher peak HRR than the B20 fuel blend, due to the better atomization and DEE.

- The B20BHT and B20 + DEE fuel blends showed higher BTE, by $6.64 \%$ and $5.4 \%$, compared to B20, respectively.

- $\quad$ BSFC were decreased by $7.69 \%$ and $3.84 \%$ with the use of BHT and DEE additives, compared to the B20 fuel blend.

- NOx emissions were decreased by $19.4 \%$ and $14.6 \%$ in the presence of BHT and DEE, respectively, compared to diesel fuel, due to higher latent heat evaporation and lower premixed combustion phase.

- B20 showed a decrease in CO emission of 31.8\%, compared to diesel fuel. However, adding DEE improved CO emissions by $39.2 \%$, compared to diesel fuel.

- HC emission was increased by $13.6 \%$ and 38\%, for B20BHT and B20DEE respectively, compared to the B20 fuel blend.

- B20DEE decreased smoke emissions by $5.4 \%$ and $11.5 \%$, respectively, compared to B20 and diesel fuel, because of the higher oxygen content in the molecule structure of DEE.

- B20BHT combustion decreased smoke emissions by 9.5\%, compared to the B20 fuel blend, because of the antioxidant's influence on reducing ignition delay.

In generall, this experimental research provides a less polluted alternative fuel, which is more beneficial for our environmental concerns.

Author Contributions: Conceptualization, S.P.S. and A.M.A.; methodology, E.K.; software, M.K.; validation, M.S., G.K.R. and P.S.; formal analysis, S.P.S.; investigation, A.M.A.; resources, S.P.S.; E.K.; data curation, M.K.; writing-original draft preparation, S.P.S. and G.K.R.; writing-review and editing, M.S., E.K. and P.S.; visualization, S.P.S. All authors have read and agreed to the published version of the manuscript.

Funding: This research received no external funding.

Institutional Review Board Statement: Not applicable.

Informed Consent Statement: Not applicable.

Data Availability Statement: Data sharing is not applicable to this article.

Conflicts of Interest: The authors declare that they have no known competing financial interests or personal relationships that could have appeared to influence the work reported in this paper.

\section{Nomenclature}

$\begin{array}{ll}\text { ATDC } & \text { after top dead center } \\ \text { B0 } & 100 \% \text { diesel fuel } \\ \text { B100 } & 100 \% \text { palm kernel oil biodiesel } \\ \text { B20 } & 20 \% \text { palm kernel oil biodiesel }+80 \% \text { diesel fuel } \\ \text { B20 + BHT } & \text { B20 + butylated hydroxyltoluene } \\ \text { B20 + DEE } & \text { B20 + diethyl ether } \\ \text { B30 } & 30 \% \text { palm kernel oil biodiesel + 70\% Diesel } \\ \text { B40 } & 40 \% \text { palm kernel oil biodiesel + 60\% Diesel } \\ \text { BHT } & \text { butylated hydroxyltoluene } \\ \text { BP } & \text { brake power } \\ \text { BSFC } & \text { brake specific fuel consumption } \\ \text { BTDC } & \text { before top dead center } \\ \text { BTE } & \text { brake thermal efficiency } \\ \text { CI } & \text { Compression ignition } \\ \text { CN } & \text { cetane number }\end{array}$




$\begin{array}{ll}\mathrm{CO} & \text { carbon monoxide } \\ \mathrm{CO}_{2} & \text { carbon dioxide } \\ \mathrm{DC} & \text { diffusion combustion } \\ \mathrm{DEE} & \text { diethyl ether } \\ \text { FFA } & \text { free fatty acid } \\ \mathrm{HHR} & \text { heat release rate } \\ \mathrm{KOH} & \text { potassium hydroxide } \\ \mathrm{NaOH} & \text { sodium hydroxide } \\ \mathrm{NOx} & \text { nitrogen oxides } \\ \mathrm{PC} & \text { premixed combustion } \\ \mathrm{PKO} & \text { palm kernel oil } \\ \mathrm{PO} & \text { palm oil } \\ \mathrm{SOC} & \text { start of combustion } \\ \mathrm{UHC} & \text { unburned hydrocarbon } \\ \text { WCO } & \text { waste cooking oil }\end{array}$

\section{References}

1. Asokan, M.; Kamesh, S.; Khan, W. Performance, combustion and emission characteristics of diesel engine fuelled with papaya and watermelon seed oil bio-diesel/diesel blends. Energy 2018, 145, 238-245. [CrossRef]

2. Gharehghani, A.; Asiaei, S.; Khalife, E.; Najafi, B.; Tabatabaei, M. Simultaneous reduction of CO and NOx emissions as well as fuel consumption by using water and nano particles in Diesel-Biodiesel blend. J. Clean. Prod. 2019, 210, 1164-1170. [CrossRef]

3. Kayode, B.; Hart, A. An overview of transesterification methods for producing biodiesel from waste vegetable oils. Biofuels 2019, 10, 419-437. [CrossRef]

4. Janaun, J.; Ellis, N. Perspectives on biodiesel as a sustainable fuel. Renew. Sustain. Energy Rev. 2010, 14, 1312-1320. [CrossRef]

5. Hosseinzadeh-Bandbafha, H.; Tabatabaei, M.; Aghbashlo, M.; Khanali, M.; Demirbas, A. A comprehensive review on the environmental impacts of diesel/biodiesel additives. Energy Convers. Manag. 2018, 174, 579-614. [CrossRef]

6. Momin, M.; Deka, D.C. Fuel property of biodiesel and petrodiesel mix: Experiment with biodiesel from yellow oleander seed oil. Biofuels 2015, 6, 269-272. [CrossRef]

7. Rajaeifar, M.A.; Tabatabaei, M.; Aghbashlo, M.; Nizami, A.-S.; Heidrich, O. Emissions from urban bus fleets running on biodiesel blends under real-world operating conditions: Implications for designing future case studies. Renew. Sustain. Energy Rev. 2019, 111, 276-292. [CrossRef]

8. Ma, F.; Hanna, M.A. Biodiesel production: A review. Bioresour. Technol. 1999, 70, 1-15. [CrossRef]

9. Bello, E.; Oguntuase, B.; Osasona, A.; Mohammed, T. Characterization and engine testing of palm kernel oil biodiesel. Eur. J. Eng. Technol. 2015, 3, 3 .

10. Gui, M.M.; Lee, K.; Bhatia, S. Feasibility of edible oil vs. non-edible oil vs. waste edible oil as biodiesel feedstock. Energy 2008, 33, 1646-1653. [CrossRef]

11. Alamu, O.; Akintola, T.; Enweremadu, C.; Adeleke, A. Characterization of palm-kernel oil biodiesel produced through NaOHcatalysed transesterification process. Sci. Res. Essay 2008, 3, 308-311.

12. Aboelazayem, O.; El-Gendy, N.S.; Abdel-Rehim, A.A.; Ashour, F.; Sadek, M.A. Biodiesel production from castor oil in Egypt: Process optimisation, kinetic study, diesel engine performance and exhaust emissions analysis. Energy 2018, 157, 843-852. [CrossRef]

13. Silitonga, A.; Masjuki, H.; Ong, H.C.; Yusaf, T.; Kusumo, F.; Mahlia, T. Synthesis and optimization of Hevea brasiliensis and Ricinus communis as feedstock for biodiesel production: A comparative study. Ind. Crop. Prod. 2016, 85, 274-286. [CrossRef]

14. Ayetor, G.; Sunnu, A.K.; Kesse, M. Engine performance and emissions of fuel produced from palm kernel oil. Biofuels 2019, 2019, 1-7. [CrossRef]

15. Nwakaire, J.; Obi, O.; Ohagwu, C.; Anyadike, C.; Ugwu, I.; Ifoh, J. Engine performance of blends of palm kernel oil biodiesel under varying speed at constant torque. Niger. J. Technol. 2020, 39, 761-766. [CrossRef]

16. Prabu, S.S.; Asokan, M.; Roy, R.; Francis, S.; Sreelekh, M. Performance, combustion and emission characteristics of diesel engine fuelled with waste cooking oil bio-diesel/diesel blends with additives. Energy 2017, 122, 638-648. [CrossRef]

17. Ryu, K. The characteristics of performance and exhaust emissions of a diesel engine using a biodiesel with antioxidants. Bioresour. Technol. 2010, 101, S78-S82. [CrossRef] [PubMed]

18. Ndayishimiye, P.; Tazerout, M. Use of palm oil-based biofuel in the internal combustion engines: Performance and emissions characteristics. Energy 2011, 36, 1790-1796. [CrossRef]

19. Imdadul, H.; Masjuki, H.; Kalam, M.; Zulkifli, N.; Alabdulkarem, A.; Rashed, M.; Teoh, Y.; How, H. Higher alcohol-biodieseldiesel blends: An approach for improving the performance, emission, and combustion of a light-duty diesel engine. Energy Convers. Manag. 2016, 111, 174-185. [CrossRef]

20. Qi, D.; Chen, H.; Geng, L.; Bian, Y. Effect of diethyl ether and ethanol additives on the combustion and emission characteristics of biodiesel-diesel blended fuel engine. Renew. Energy 2011, 36, 1252-1258. [CrossRef] 
21. Imtenan, S.; Masjuki, H.H.; Varman, M.; Fattah, I.R.; Sajjad, H.; Arbab, M. Effect of n-butanol and diethyl ether as oxygenated additives on combustion-emission-performance characteristics of a multiple cylinder diesel engine fuelled with diesel-jatropha biodiesel blend. Energy Convers. Manag. 2015, 94, 84-94. [CrossRef]

22. Huaping, Z.; Zongbin, W.; Yuanxiong, C.; Zhang, P.; Shijie, D.; Xiaohua, L.; Zongqiang, M. Preparation of biodiesel catalyzed by solid super base of calcium oxide and its refining process. Chin. J. Catal. 2006, 27, 391-396.

23. Chitsaz, H.; Omidkhah, M.; Ghobadian, B.; Ardjmand, M. Optimization of hydrodynamic cavitation process of biodiesel production by response surface methodology. J. Environ. Chem. Eng. 2018, 6, 2262-2268. [CrossRef]

24. Holman, J. Experimental Methods for Engineers, 7th ed.; Tata McGraw Hill: New Delhi, India, 2004.

25. Kudre, T.G.; Bhaskar, N.; Sakhare, P.Z. Optimization and characterization of biodiesel production from rohu (Labeo rohita) processing waste. Renew. Energy 2017, 113, 1408-1418. [CrossRef]

26. Prabu, S.S.; Asokan, M.; Prathiba, S.; Ahmed, S.; Puthean, G. Effect of additives on performance, combustion and emission behavior of preheated palm oil/diesel blends in DI diesel engine. Renew. Energy 2018, 122, 196-205. [CrossRef]

27. Imtenan, S.; Masjuki, H.; Varman, M.; Kalam, M.; Arbab, M.; Sajjad, H.; Ashrafur Rahman, S. Impact of oxygenated additives to palm and jatropha biodiesel blends in the context of performance and emissions characteristics of a light-duty diesel engine. Energy Convers. Manag. 2014, 83, 149-158. [CrossRef]

28. Khalife, E.; Tabatabaei, M.; Demirbas, A.; Aghbashlo, M. Impacts of additives on performance and emission characteristics of diesel engines during steady state operation. Prog. Energy Combust. Sci. 2017, 59, 32-78. [CrossRef]

29. Soriano, J.; García-Contreras, R.; Gómez, A.; Mata, C. Comparative study of the effect of a new renewable paraffinic fuel on the combustion process of a light-duty diesel engine. Energy 2019, 189, 116337. [CrossRef]

30. Elkelawy, M.; Etaiw, S.E.-d.H.; Bastawissi, H.A.-E.; Ayad, M.I.; Radwan, A.M.; Dawood, M.M. Diesel/biodiesel/silver thiocyanate nanoparticles/hydrogen peroxide blends as new fuel for enhancement of performance, combustion, and Emission characteristics of a diesel engine. Energy 2021, 216, 119284. [CrossRef]

31. Asokan, M.; Vijayan, R.; Prabu, S.S.; Venkatesan, N. Experimental studies on the combustion characteristics and performance of a DI diesel engine using kapok oil methyl ester/diesel blends. Int. J. Oil Gas Coal Technol. 2016, 12, 105-119. [CrossRef]

32. Khalife, E.; Tabatabaei, M.; Najafi, B.; Mirsalim, S.M.; Gharehghani, A.; Mohammadi, P.; Aghbashlo, M.; Ghaffari, A.; Khounani, Z.; Roodbar Shojaei, T.; et al. A novel emulsion fuel containing aqueous nano cerium oxide additive in diesel-biodiesel blends to improve diesel engines performance and reduce exhaust emissions: Part I—Experimental analysis. Fuel 2017, 201. [CrossRef]

33. Erdoğan, S.; Balki, M.K.; Aydın, S.; Sayın, C. Performance, emission and combustion characteristic assessment of biodiesels derived from beef bone marrow in a diesel generator. Energy 2020, 207, 118300. [CrossRef]

34. Ren, Y.; Huang, Z.; Miao, H.; Di, Y.; Jiang, D.; Zeng, K.; Liu, B.; Wang, X. Combustion and emissions of a DI diesel engine fuelled with diesel-oxygenate blends. Fuel 2008, 87, 2691-2697. [CrossRef]

35. Attia, A.M.; Hassaneen, A.E. Influence of diesel fuel blended with biodiesel produced from waste cooking oil on diesel engine performance. Fuel 2016, 167, 316-328. [CrossRef]

36. Tompkins, B.; Song, H.; Bittle, J.; Jacobs, T. Efficiency considerations for the use of blended biofuel in diesel engines. Appl. Energy 2012, 98, 209-218. [CrossRef]

37. Asokan, M.; Prabu, S.S.; Akhil, V.S.; Bhuvan, P.S.; Reddy, Y.B. Performance and emission behaviour of diesel and blends of watermelon seed oil biodiesel in direct injection diesel engine. Mater. Today Proc. 2021, 45, 3274-3278. [CrossRef]

38. Gumus, M.; Sayin, C.; Canakci, M. The impact of fuel injection pressure on the exhaust emissions of a direct injection diesel engine fueled with biodiesel-diesel fuel blends. Fuel 2012, 95, 486-494. [CrossRef]

39. Kumar, M.V.; Babu, A.V.; Kumar, P.R. The impacts on combustion, performance and emissions of biodiesel by using additives in direct injection diesel engine. Alex. Eng. J. 2018, 57, 509-516. [CrossRef]

40. Kumar, A.N.; Kishore, P.; Raju, K.B.; Nanthagopal, K.; Ashok, B. Experimental study on engine parameters variation in CRDI engine fuelled with palm biodiesel. Fuel 2020, 276, 118076. [CrossRef]

41. Pidol, L.; Lecointe, B.; Starck, L.; Jeuland, N. Ethanol-biodiesel-diesel fuel blends: Performances and emissions in conventional diesel and advanced low temperature combustions. Fuel 2012, 93, 329-338. [CrossRef]

42. Varatharajan, K.; Cheralathan, M.; Velraj, R. Mitigation of NOx emissions from a jatropha biodiesel fuelled DI diesel engine using antioxidant additives. Fuel 2011, 90, 2721-2725. [CrossRef]

43. Heywood, J.B. Internal Combustion Engine Fundamentals; McGraw-Hill: New York, NY, USA, 1988; Volume 930.

44. Ozsezen, A.N.; Canakci, M. The emission analysis of an IDI diesel engine fueled with methyl ester of waste frying palm oil and its blends. Biomass Bioenergy 2010, 34, 1870-1878. [CrossRef]

45. Hosseinzadeh-Bandbafha, H.; Tabatabaei, M.; Aghbashlo, M.; Khanali, M.; Khalife, E.; Shojaei, T.R.; Mohammadi, P. Consolidating emission indices of a diesel engine powered by carbon nanoparticle-doped diesel/biodiesel emulsion fuels using life cycle assessment framework. Fuel 2020, 267, 117296. [CrossRef]

46. Sayin, C.; Canakci, M. Effects of injection timing on the engine performance and exhaust emissions of a dual-fuel diesel engine. Energy Convers. Manag. 2009, 50, 203-213. [CrossRef]

47. Ajav, E.; Singh, B.; Bhattacharya, T. Experimental study of some performance parameters of a constant speed stationary diesel engine using ethanol-diesel blends as fuel. Biomass Bioenergy 1999, 17, 357-365. [CrossRef]

48. Asokan, M.; Prabu, S.S.; Bade, P.K.K.; Nekkanti, V.M.; Gutta, S.S.G. Performance, combustion and emission characteristics of juliflora biodiesel fuelled DI diesel engine. Energy 2019, 173, 883-892. [CrossRef] 
49. Asokan, M.; Vijayan, R. A review on performance, emission and combustion characteristics of a diesel engine fuelled with various vegetable oil. Indian J. Chem. Technol. 2018, 25, 225-234.

50. Monsalve-Serrano, J.; Belgiorno, G.; Di Blasio, G.; Guzmán-Mendoza, M. 1D simulation and experimental analysis on the effects of the injection parameters in methane-diesel dual-fuel combustion. Energies 2020, 13, 3734. [CrossRef]

51. Sayin Kul, B.; Kahraman, A. Energy and exergy analyses of a diesel engine fuelled with biodiesel-diesel blends containing $5 \%$ bioethanol. Entropy 2016, 18, 387. [CrossRef]

52. Belgiorno, G.; Dimitrakopoulos, N.; Di Blasio, G.; Beatrice, C.; Tuner, M.; Tunestal, P. Parametric Analysis of the Effect of Pilot Quantity, Combustion Phasing and EGR on Efficiencies of a Gasoline PPC Light-Duty Engine. SAE Tech. Paper 2017. [CrossRef] 